\title{
Variation of Lp(a) Plasma Concentrations in Health and Disease
}

\author{
R. Siekmeier*, , H. Scharnagl ${ }^{2}$, G.M. Kostner ${ }^{3}$, T. Grammer ${ }^{4}$, T. Stojakovic ${ }^{2}$ and W. März ${ }^{4}$
}

\author{
${ }^{I}$ Bundesinstitut für Arzneimittel und Medizinprodukte (BfArM), Kurt-Georg-Kiesinger-Allee 3, Bonn, Deutschland, \\ Germany \\ ${ }^{2}$ Klinisches Institut für Medizinische und Chemische Labordiagnostik, Medizinische Universität Graz, Graz, Österreich, \\ Austria \\ ${ }^{3}$ Institut für Medizinische Biochemie und Medizinische Molekularbiologie, Medizinische Universität Graz, Graz, \\ Österreich, Austria \\ ${ }^{4}$ Synlab - Medizinisches Versorgungszentrum für Labordiagnostik, Heidelberg, Eppelheim, Deutschland, Germany
}

\begin{abstract}
Lipoprotein(a) (Lp(a)) is an established risk marker of cardiovascular diseases which is independent from other risk markers. The main difference of $\mathrm{Lp}$ (a) compared to low density lipoprotein (LDL) is the apo(a) residue which is covalently bound to apoB. Apo(a) is a glycoprotein which underlies a large genetic polymorphism. The latter is caused by a variation of the kringle-IV-type-2 repeats of the protein which is characterized by a large structural homology to plasminogen. The Lp(a) plasma concentration in the population is highly skewed and determined to more than $90 \%$ by genetic factors. In healthy subjects the $\mathrm{Lp}$ (a)-concentration is correlated to its synthesis and not to its metabolism. However, plasma concentrations of $\mathrm{Lp}(\mathrm{a})$ are also affected by different diseases (e.g. diseases of liver and kidney), hormonal factors (e.g. sexual steroids, glucocorticoids, thyroid hormones), individual and environmental factors (e.g. age, cigarette smoking) as well as pharmaceuticals (e.g. derivatives of nicotinic acid) and therapeutic procedures (lipid apheresis). Aim of this review was to describe the physiological regulation of Lp(a) as well as factors influencing its plasma concentration.
\end{abstract}

Keywords: Lipoprotein (a), plasma lipoproteins, atherosclerosis, coronary heart disease.

\section{INTRODUCTION}

Lipoprotein (a) (Lp(a)), for the first time described in 1963 by Berg belongs to the lipoproteins with the strongest atherogenic effect $[1,2]$. Its importance for the development of various atherosclerotic vasculopathies (coronary heart disease, ischemic stroke, peripheral vasculopathy, abdominal aneurysm), however, was recognized considerably later [36]. With regard to its structure, $\operatorname{Lp}(\mathrm{a})$ is a low density lipoprotein (LDL), to whose apolipoprotein B (apoB) another protein, i. e. apolipoprotein(a) (apo(a)), is covalently bound by a disulfide-bridge [7]. The physiological function of $L p(a)$ is unknown to date, since test persons with very low or not detectable $\mathrm{Lp}(\mathrm{a})$ plasma concentrations do not present a specific phenotype. Vice versa, however, numerous studies have shown that elevated $\mathrm{Lp}$ (a) plasma concentrations are associated with an increased risk of atherosclerotic diseases (coronary heart disease, peripheral arterial occlusive disease, cerebral stroke) [6-11]. Apo(a) synthesis is performed in the liver, probably followed by extracellular assembly to the apoB location of the LDL [12]. The biological half life of $\mathrm{Lp}(\mathrm{a})$ is known by kinetic investigations and exceeds the half life of LDL $[13,14]$. However, only little is known about the

*Address correspondence to this author at the Bundesinstitut für Arzneimittel und Medizinprodukte, (BfArM), Kurt-Georg-Kiesinger-Allee 3, 53175 Bonn, Germany; Tel: 0049/228-207-5360; Fax: 0049/228-2075300; E-mail: r.siekmeier@bfarm.de details of $\mathrm{Lp}$ (a) catabolizm. It is assumed that the kidney has a specific function in $\mathrm{Lp}$ (a) catabolizm, since nephrotic syndrome and terminal kidney failure are associated with an elevation of the $\mathrm{Lp}(\mathrm{a})$ plasma concentration $[15,16]$. One consequence of the poor knowledge of the metabolic path of $L p(a)$ is the fact that so far pharmaceutical science has failed to develop drugs that are able to reduce elevated $L p(a)$ plasma concentrations to the desired extent.

\section{STRUCTURE OF LP(a)}

$\mathrm{Lp}(\mathrm{a})$ is a complex particle which mainly consists of a part that is similar to LDL, to whose apoB glycoprotein apo(a) is covalently bound. To a small extent, however, apo(a) could also be detected bound to triglyceride-rich lipoproteins (Very Low Density Lipoproteins; VLDL). Corresponding to the structural similarity to LDL, both particles are very similar to each other with regard to their composition [13]. Apo(a) shows a distinct structural homology to plasminogen, whose gene is also localised on chromosome 6 [17, 18]. The kringle repeats present a particularly characteristic structure, which have a high similarity to kringle IV (K IV) of plasminogen. Additionally, apo(a) presents a kringle $\mathrm{V}$ structure of plasminogen and also a protease domain, which cannot be activated, as opposed to the one of plasminogen [2, 17, 18] (Fig. 1). At least 30 genetically determined apo(a) isoforms were identified in man, which are the basis for the marked 


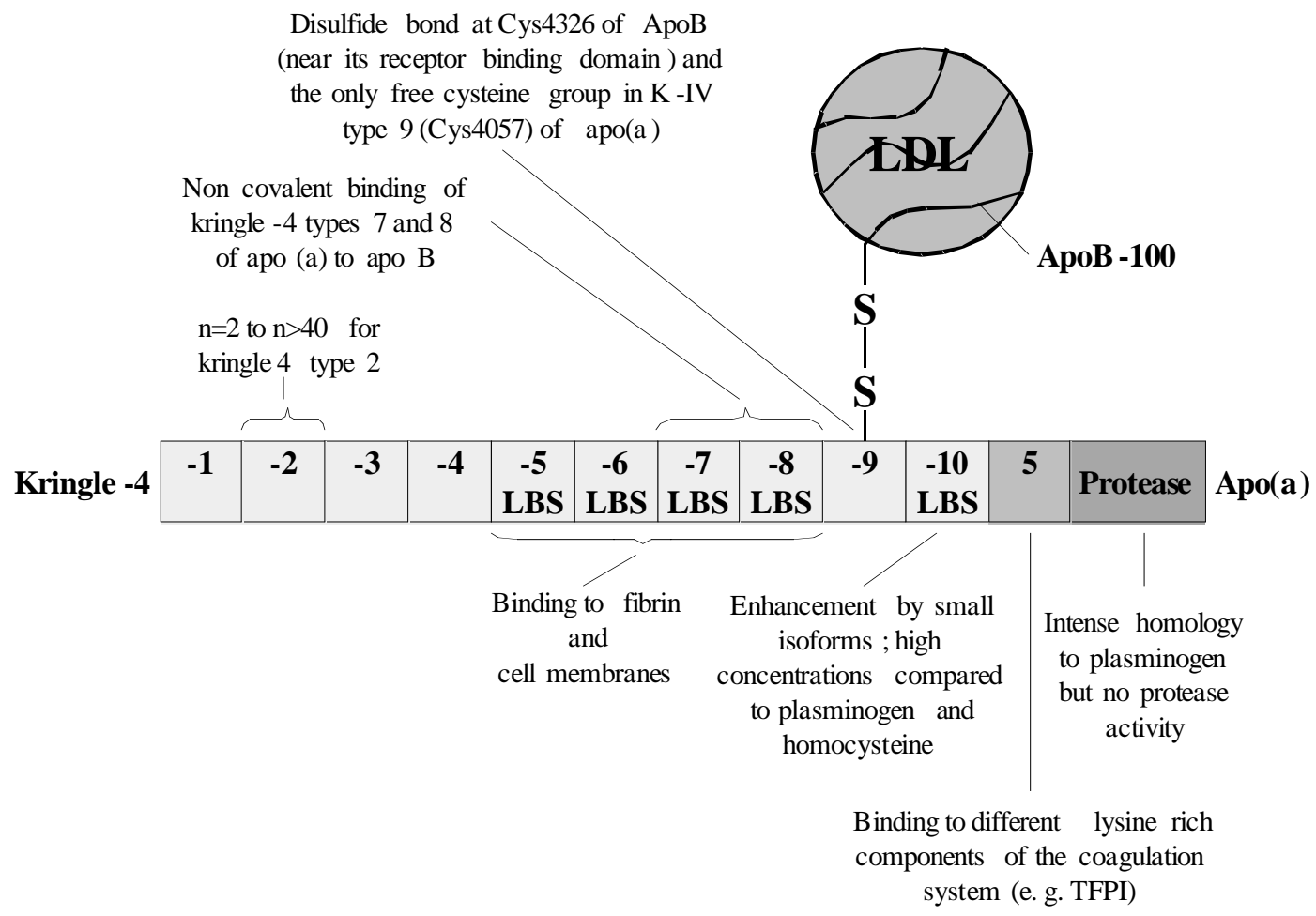

Fig. (1). Structure of $\operatorname{Lp}(a)$.

heterogeneity of the molecular size. The individual apo(a) isoforms differ by the number of K IV units in the molecule, i. e. corresponding to a molecular weight of approximately $12.5 \mathrm{kDa}$ per $\mathrm{K}$ IV-unit $[2,17]$. The smallest apo(a) isoform consists of one protease domain, one $\mathrm{K} \mathrm{V}$-unit and $11 \mathrm{~K} \mathrm{IV}$ units, while the apo(a) isoform of the highest molecular weight has $52 \mathrm{~K} \mathrm{IV-units.} \mathrm{Between} \mathrm{the} \mathrm{individual} \mathrm{K} \mathrm{IV-units}$ there are highly glycosylated connection units which are responsible for the high share of glycoproteins in the whole molecule [2].

\section{LP(a) METABOLIZM}

Apo(a) is synthesized at least predominantly in the liver. After its synthesis it binds with high affinity to the apoB binding site of LDL. Probably, the binding is completed on the hepato-cellular surface via a disulfide-bridge of the Cys4326 of apoB and the only free cysteine group in K IV type 9 (Cys4057) of apo(a) [2, 19]. The synthesis of $\mathrm{Lp}(\mathrm{a})$, which thus occurs as part of an assembly, is a two-step process [20]. In a first step, which can be competitively inhibited by lysine analogues, the free sulfhydryl groups of apo(a) and apoB are brought close together. The binding of apo(a) then occurs near the apoB domain which binds to the LDL receptor, resulting in a reduced affinity of $L p(a)$ to the LDL-receptor. Particles that show a reduced affinity to the LDL receptor, such as particles containing apoB-48 and VLDL, are not able to form stable compounds with apo(a) [2]. Thus the largest part of apo(a) is present as apo(a) bound to LDL. Only a small, quantitatively variable part of apo(a) remains as free apo(a) and probably plays an important role in the metabolizm and physiological function of $\operatorname{Lp}(\mathrm{a})[2$, 21]. The synthesis rate of $L p(a)$ is strongly related to its plasma concentration and therefore depends on the apo(a) isoform that determines plasma concentration, while the catabolizm rate is only of little significance [14].

The metabolic path of the synthesised $\mathrm{Lp}(\mathrm{a})$ is largely not yet understood. Due to the structural similarity of LDL and $\mathrm{Lp}(\mathrm{a})$ it was first assumed that $\mathrm{Lp}(\mathrm{a})$, like other apo B containing lipoproteins, is degraded via the LDL-receptor. Thus it could be shown in in vitro experiments that the binding of $\mathrm{Lp}(\mathrm{a})$ to fibroblasts could be competitively inhibited by addition of LDL, but compared to LDL, Lp(a) only had a small affinity to the LDL receptor. Animal experiments (rat, rabbit, hedgehog) showed that the liver plays an important role in $\mathrm{Lp}(\mathrm{a})$ metabolism - followed by kidney and spleen [13]. On the other hand, kinetic investigations performed in man, which demonstrated a longer plasma half life for $\mathrm{Lp}$ (a) compared to LDL, allowed the conclusion that the LDL receptor practically has no function in the metabolism of $\operatorname{Lp}(\mathrm{a})$. Thus the fractional catabolic rates for $\mathrm{LDL}$ and $\mathrm{Lp}(\mathrm{a})$ are 0.38 and 0.26 , respectively, in normal persons and are practically the same as for homozygotic patients with a defect on the LDL receptor $(0.205$ and 0.210 , respectively) [13, 14]. This phenomenon was the reason that other metabolic paths are now being discussed for $\mathrm{Lp}(\mathrm{a})$. Apo(a) obviously separates from apoB in the blood and as a consequence it comes to a subsequent fragmentation into degradation products of different molecular weight induced by metalloproteinases [2, 22]. As could be shown in experiments in transgenic mice, the resulting degradation products are removed from circulation by different organs and tissues, and only a very small part of them (less than $1 \%$ of $\mathrm{Lp}(\mathrm{a})$ ) is excreted with the urine $[2,22,23]$. Other, receptor-dependent metabolic paths are assumed for the $\mathrm{Lp}(\mathrm{a})$ metabolism. Among them are LDL-receptor related protein, megalin, the VLDL 
receptor and the galactose-specific asialoglycoprotein receptor (ASGPR) [2, 24].

\section{GENETICS AND PLASMA CONCENTRATION}

The plasma concentration of $\mathrm{Lp}(\mathrm{a})$ is highly skewed with regard to its frequency, whereby the concentrations among different individuals may differ by factor 1000 [13, 25, 26]. The white population shows a median of the $\mathrm{Lp}(\mathrm{a})$ concentration of approximately $8 \mathrm{mg} / \mathrm{dL}$ to $10 \mathrm{mg} / \mathrm{dL}$, while the mean values are at an approximate level of $16 \mathrm{mg} / \mathrm{dL}$ to $18 \mathrm{mg} / \mathrm{dL}[13,27]$. In contrast, plasma concentrations in Black Africans are twice as high as in Caucasians, while those of Asian individuals are distinctly below that value. However, the underlying causes of these differences are not finally identified [2]. The concentrations are strictly determined by genetic factors, i. e. to an extent of $90 \%$ to 95 $\%$, and are subject to only low variations during lifetime [13, 28]. In detail, a total of $50 \%$ of the plasma concentration is determined by the respective number of kringle-IV-domains, while approximately $45 \%$ of the genetic variation of the plasma concentrations are attributable to polymorphisms and mutations of the promoter region (pentanucleotide repeat, TTTTA), to the coding regions (+93 C/T polymorphism) and to other variations of the apo(a) gene [2, 13]. Despite this $\mathrm{Lp}$ (a) plasma concentrations continuously rise mainly in the first weeks after birth and also in the course of the later decades in life [2]. There is a distinct inverse correlation between the respective molecular weight of $\mathrm{Lp}(\mathrm{a})$ determined by the number of kringle-IV-domains in the apo(a) part of the lipoprotein particle and the individual plasma concentrations, respectively. Thus individuals with a high Lp(a) molecular weight show low plasma concentrations, while individuals with a low $\mathrm{Lp}(\mathrm{a})$ molecular weight present high plasma concentrations [12, 29, 30]. This can be explained by the fact that apo(a) isoforms with a high molecular weight are stronger bound and degraded in the rough endoplasmic reticulum, in the golgi apparatus and in proteasomes than apo(a) isoforms with a low molecular weight $[31,32]$.

\section{PHYSIOLOGICAL FUNCTIONS OF LP(a)}

Based on the results of the initial investigations by Berg [1], the opinion prevailed for many years, that individuals without detectable Lp(a) plasma concentrations (so-called Lp(a)-negative individuals) did not have any defect. But due to the increasing sensitivity of the analytical procedures used in the detection it could be shown that the plasma concentrations of these individuals were only below 25 $\mathrm{mg} / \mathrm{dL}$. Later investigations in individuals with $\mathrm{Lp}$ (a) plasma concentrations of $<0.5 \mathrm{mg} / \mathrm{dL}$ showed a disproportionately high excretion of apo(a) fragments in the urine of these individuals [2]. Now results of further investigations allow the conclusion that apart from its significance as an important agent in the development of atherosclerosis, $\mathrm{Lp}$ (a) has even more physiological functions, e.g. in wound healing, angiogenesis and hemostasis [2, 17, 33, 34] (Fig. 2). However, in the meaning of a pleiotropic mechanism the favorable action mechanisms are opposed by pathogenetic mechanisms, whereby the importance of $L p(a)$ in atherogenesis should be particularly mentioned $[8-10,17,33$, 34].

\section{$\mathbf{L p}(\mathbf{a})$ in Atherosclerosis}

The importance of $\mathrm{Lp}(\mathrm{a})$ in the formation and progression of atherosclerotic vascular diseases could be demonstrated in numerous animal experiments. Thus evidence was supplied that in transgenic, hyperlipidemic and $\mathrm{Lp}(\mathrm{a})$ expressing Watanabe rabbits, Lp(a) leads to enhanced atherosclerosis with development of calcifications [35-37]. Under the influence of $\mathrm{Lp}(\mathrm{a})$, the binding of $\mathrm{Lp}(\mathrm{a})$ to glycoproteins, e.g. laminin, results - via its apo(a)-part [38$40]$ - both in an increased invasion of inflammatory cells [41, 42] and in an activation of smooth vascular muscle cells with an increased formation of alkaline phosphatase and subsequent calcifications [36, 37] in the vascular wall. The inhibition of transforming growth factor- $\beta 1$ (TGF- $\beta 1$ ) activation is another mechanism via which Lp(a) contributes to the development of atherosclerotic vasculopathies. TGF- $\beta 1$ is subject to proteolytic activation by plasmin and its active form leads to an inhibition of the proliferation and migration of smooth muscle cells, which play a central role in the formation and progression of atherosclerotic vascular diseases [43-46]. If TGF- $\beta 1$ fails to be activated, e.g. due to $\mathrm{Lp}$ (a) accumulation in the vascular wall, it is associated with an increased proliferation and migration of the smooth vascular muscle cells and the formation of atherosclerotic lesions [43, 44, 47, 48].

In man, $\mathrm{Lp}(\mathrm{a})$ is an important risk marker which is independent of other risk markers. Its importance, partly also under consideration of the molecular weight and other genetic polymorphisms, could be demonstrated by a high number of epidemiological and clinical studies investigating the formation and progression of atherosclerosis, myocardial infarction, and stroke and also by meta-analyses [8-10, 34, 49]. The simultaneous presence of other risk markers, e.g. hypercholesterolemia, hyperfibrinogenemia or reduced HDL-cholesterol, will lead to an even stronger increase of the total risk for the occurrence of cardiovascular diseases due to $L p(a)$ [10, 49-51]. However, there are other studies that could not find evidence for the role of $\mathrm{Lp}(\mathrm{a})$ as a risk marker for cardiovascular diseases, e.g. the Physicians Health Study [2, 52]. Possible causes for such negative results may be performance of analyses with samples that were stored for too long and the use of insufficiently validated test kits, but also the investigation of smaller study populations, which are subject to an increased influence of the skewed distribution of the $\mathrm{Lp}(\mathrm{a})$ plasma concentration in the population $(<0.1 \mathrm{mg} / \mathrm{dL}$ up to $>300 \mathrm{mg} / \mathrm{dL})$ [2].

\section{Lp(a) in Hemostasis}

Due to the marked structural homology between the apo(a) part and plasminogen, which both belong to the socalled plasminogen group [18], a relationship between the coagulation system and Lp(a) was assumed quite early [53]. $\mathrm{Lp}(\mathrm{a})$ is able to competitively inhibit the binding of plasminogen to fibrinogen and fibrin, and to inhibit the fibrin-dependent activation of plasminogen to plasmin via the tissue plasminogen activator [53-55], whereby apo(a) isoforms of low molecular weight have a higher affinity to fibrin than apo(a) isoforms of higher molecular weight [54]. Like other compounds containing sulfhydryl groups, homocysteine enhances the binding of $\mathrm{Lp}$ (a) to fibrin [56]. During fibrinolysis, physiological importance of which lies 


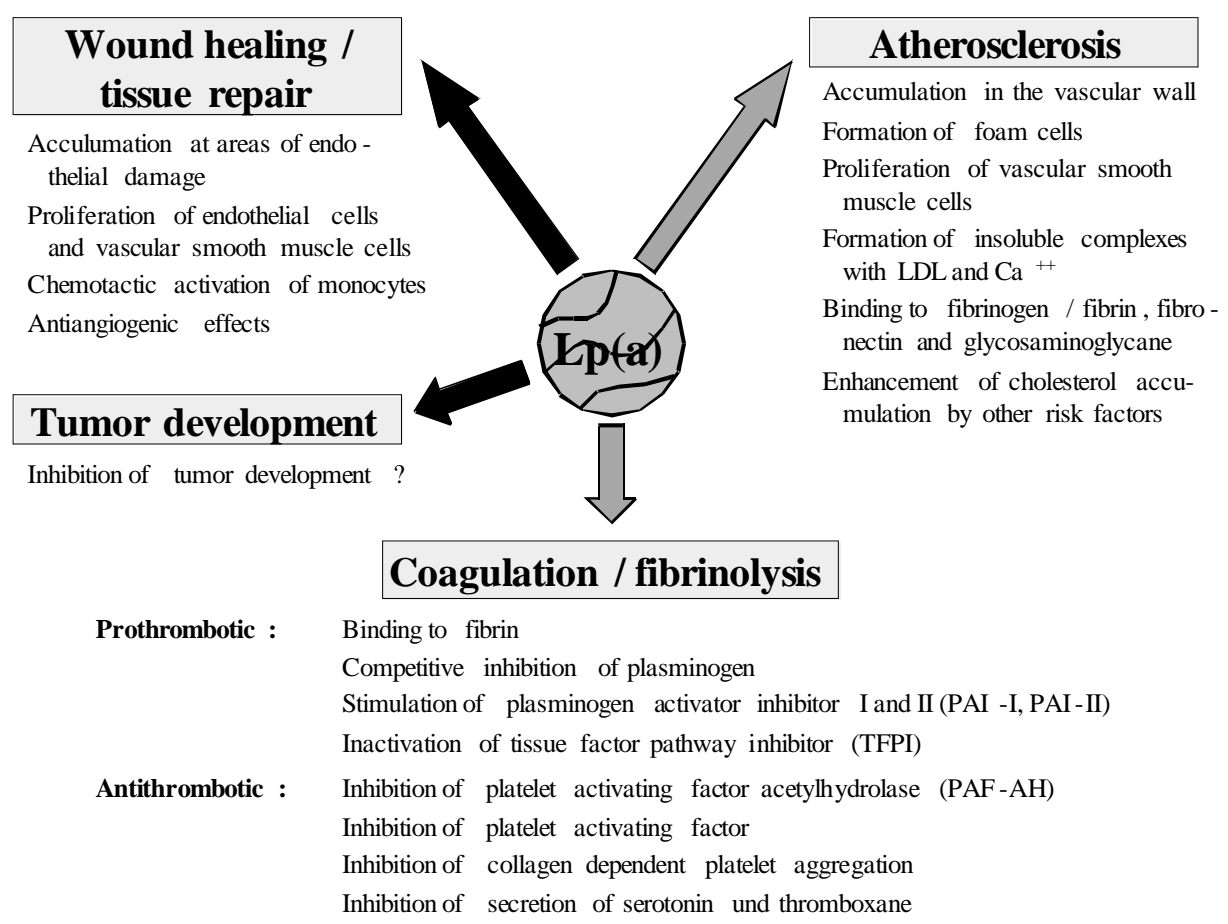

Fig. (2). Pleiotropic effect of Lp(a).

in the dissolution of fibrin deposits and in the restoration of an injured vascular endothelium [57], the binding of plasminogen to lysine residues results in plasmin activation and subsequently in the enhancement of the following fibrinolytic processes [58-63]. Lp(a) binding also involves lysine [54] with the consequence, that due to the lack of catalytic activity it comes to hypofibrinolysis and, due to the LDL-component of the $\mathrm{Lp}(\mathrm{a})$, to an accumulation of cholesterol [2, 17, 18, 33, 54, 64-66]. Moreover, Lp(a) stimulates the synthesis of plasminogen activator-inhibitor I (PAI-I) in endothelial cells or of PAI-II in monocytes [2, 67]. The thus induced decrease of plasmin activity is not only important for the fibrinolytic system, since plasmin is also required for the activation of transforming growth factor- $\beta 1$ (TGF- $\beta 1$ ) which plays an important role in the proliferation and migration of the smooth vascular muscle cells within the atherosclerotic process [43]. Another relationship, which also favours the formation of thromboses, between $\mathrm{Lp}(\mathrm{a})$ and the fibrinolytic system is found in its property, to bind to the tissue factor pathway inhibitor (TFPI), a regulator of the tissue factor (TF)-mediated coagulation, expressed in activated monocytes, endothelial cells and thrombocytes [33, 68-72], and to subsequently inactivate this factor [73]. But in addition to the mentioned prothrombotic properties $\mathrm{Lp}(\mathrm{a})$ also has antithrombotic properties. Thus Lp(a) binds with high affinity and specificity to the platelet activating factor acetylhydrolase. This does not only result in the inhibition of PAF, one of the strongest trigger factors of thrombocyte aggregation, but also in the hydrolysis of the short-chain phospholipids that develop during the process of lipid oxidation [2, 74-76]. Additionally, Lp(a) also leads to the inhibition of the collagen-induced thrombocyte aggregation and to the inhibition of serotonin and thromboxane secretion $[2,77]$. In summary it shows that via various mechanisms
Lp(a) possesses both prothrombotic and antithrombotic properties, which may be an explanation for the contradictory trial results achieved in different patient cohorts, since the properties of $\mathrm{Lp}(\mathrm{a})$ find different expression [2].

Several studies demonstrate a role of $\mathrm{Lp}(\mathrm{a})$ as an important risk marker, partly independent of other risk markers, for the occurrence of an acute coronary syndrome and spontaneous, partly recurring, ischemic strokes and of venous thromboses and thromboembolism in children and adults [33, 78-84], while other investigations did not establish any relationship between the occurrence of thrombotic events or thromboembolism and the existence of an elevated $\mathrm{Lp}$ (a) plasma concentration [85-87]. Moreover, elevated $\mathrm{Lp}$ (a) plasma concentrations were measured in a number of studies performed in patients with early-stage or terminal kidney diseases and autoimmune diseases (antiphospholipid syndrome, systemic sclerosis, chronic thromboembolic pulmonary hypertension, rheumatoid arthritis and systemic lupus erythematosus), which fact supports the involvement of $\mathrm{Lp}(\mathrm{a})$ in the increased occurrence of thromboembolic events [88-97].

\section{Lp(a) in Angiogenesis}

$\mathrm{Lp}(\mathrm{a})$ is also important for the process of angiogenesis and the sprouting of new vessels. This is based on the fact that angiogenesis starts with the remodelling of matrix proteins and the activation of matrix metalloproteinases (MMP). The latter ones are usually synthesised as inactive zymogens and require activation by proteases, this is also accomplished by plasminogen. The marked structural homology of $\mathrm{Lp}(\mathrm{a})$ to plasminogen, with a simultaneous lack 
of protease activity, may indicate that $\mathrm{Lp}(\mathrm{a})$ has an antiangiogenetic effect $[2,98]$. Accordingly, an antiangiogenetic and metastasis inhibiting effect of $\mathrm{Lp}(\mathrm{a})$ and apo(a) and its fragments could be demonstrated in mice and in vitro [98-105].

Finally it should be stated that elevated Lp(a) plasma concentrations are found in individuals over eighty years and in tumor patients, as opposed to healthy individuals. These increases indicate that individuals with higher $\mathrm{Lp}(\mathrm{a})$ concentrations, provided they do not develop atherosclerosis, may have a certain protection against tumor diseases or that $\mathrm{Lp}$ (a) may have a certain function in tumor defence $[2,106]$. Likewise, the plasminogen fragments have an antiangiogenetic effect due to their homologous structure [106]. In summary it can be said, however, that the possible relationships between an antiangiogenetic effect of $\mathrm{Lp}(\mathrm{a})$ and a possible protection against tumor formation are only insufficiently known and require extensive further experimental investigation.

\section{INFLUENCE OF CERTAIN DISEASES ON LP(a) PLASMA CONCENTRATION}

A number of different diseases (e.g. liver diseases, kidney diseases and acute phase response) hormones (thyroid hormones, androgens and estrogens) life style factors (e.g. nutrition, sports and cigarette smoking) as well therapeutic interventions (e.g. nicotinic acid, fibrates, lipid apheresis) are affecting the plasma concentration of $\mathrm{Lp}(\mathrm{a})$. However, these effects are very complex and often strongly depend on type and severity of the disease as well as type and dose of the administered pharmaceutical. A number of these factors are discussed in the following in more detail.

\section{Liver Diseases}

Cholestatic liver diseases especially those with strongly elevated plasma concentrations of lipoprotein-X are typically correlated with lower plasma concentrations of $\mathrm{Lp}(\mathrm{a})$. It is discussed that this is caused by a lack of LDL in plasma followed by an impaired assembly of LDL and apo(a) [2]. For example, Gregory et al. observed decreased Lp(a) plasma concentrations in patients with primary biliary cirrhosis (PBC) and other liver diseases [107]. A decrease of $\mathrm{Lp}$ (a) plasma concentration was also observed in patients with different acute or chronic viral liver infections as well as liver failure [108, 109] and liver cirrhosis [110]. Conflicting data are published for patients with hepatocellular carcinoma who showed decreased [111, 112] as well as increased [111, 113] plasma concentrations of this lipoprotein. In another study Koruk et al. found no difference of $\mathrm{Lp}$ (a) plasma concentrations in patients with non-alcoholic steatohepatitis compared to healthy individuals [114]. Finally, it should be mentioned that no $\mathrm{Lp}$ (a) can be detected in patients with paroxysmal diseases. It is suggested that this is caused by a lack of apo(a) secretion [115].

\section{Kidney Diseases}

The effect of various renal diseases on plasma concentrations and metabolism of lipoproteins including $\mathrm{Lp}$ (a) was subject of a large number of studies. Increased plasma concentrations of $\mathrm{Lp}(\mathrm{a})$ were observed in patients with diabetic microalbuminuria $[10,116,117]$, nephrotic syndrome [10, 93, 97, 118-120], nephropathy [10, 117] and different type and stage of kidney failure [10, 92, 93, 95, 96, $110,121-127]$. These observations suggest that $\mathrm{Lp}(\mathrm{a})$ plays a crucial role for the development of cardiovascular diseases in patients with kidney diseases. However, the results of these studies are conflicting in respect to the role of the genetically determined molecular weight of apo(a) [10, 92, 121-123, 124, 127-131].

\section{Acute Phase Reactions}

Due to the regulation of its synthesis by interleukin 6 (IL6) $L p(a)$ in some respect is an acute phase protein. In consequence, inflammatory stimuli are able to affect the Lp(a) plasma concentration [126, 132]. Increased concentrations in different extent were found in chronic diseases as rheumatoid arthritis [133] or kidney disease [127], drug induced acute phase response (e.g. bisphosphonates [134]) and acute diseases as myocardial infarction or cardiovascular bypass surgery [135-139] but not after strong physical exercise [140]. However, in cases of severe inflammation due to sepsis or burn a decrease of $\mathrm{Lp}$ (a) plasma concentration was observed indicating a role of additional regulatory factors in critically ill patients [141].

\section{Hormones}

Different hormones affect the plasma concentration of $\mathrm{Lp}(\mathrm{a})$. This effect is independent from the effects on the other lipoproteins and in some cases it can be oppositional. In addition, even synthetic hormones can cause a variation of the $\mathrm{Lp}$ (a) plasma concentration. The hormonal effects of some natural or synthetic hormones as well as hormonal deprivation are described below in more detail.

\section{Thyroid Hormones}

Patients suffering from hypo- or hyperthyroidism show distinct changes of lipid metabolism and corresponding changes of the different plasma lipoproteins $[2,13,142$ 145]. In principle, hypothyroidism causes an increase of Lp(a) plasma concentration whereas hyperthyroidism causes a decrease of its concentration. However, the results of the studies are conflicting. For example, Dullaart et al. investigated patients after radical thyroidectomie due to carcinoma and found an increase of the $\mathrm{Lp}$ (a) plasma concentration within the hypothyroid phase [142]. Increases of $\mathrm{Lp}$ (a) were also observed in other hypothyroid patients compared to healthy euthyroid controls [146-148]. In one of these studies there was a correlation between the plasma concentrations of $\mathrm{Lp}(\mathrm{a})$ and the concentrations of thyroidea stimulating hormone (TSH) which serves as a marker for the intensity of hypothyroidism. [146]. On the other hand Lee et al. observed no increase of the $\mathrm{Lp}$ (a) plasma concentration in patients with manifest hypothyroidism compared to healthy controls [149]. The results obtained in patients with subclinical hypothyroidism are also conflicting. Some investigators observed increases of $\mathrm{Lp}(\mathrm{a})$ plasma concentration in these patients compared to controls [150153] whereas others did not [148, 149]. Milionis et al. also determined the molecular weight of $\mathrm{Lp}(\mathrm{a})$. However, there was no effect of the molecular weight on the Lp(a) plasma concentration before treatment. Furthermore, there was no correlation between the plasma concentrations of $\mathrm{Lp}(\mathrm{a})$ and 
TSH [152]. Results of studies evaluating the effect of hyperthyroidosis on $\mathrm{Lp}$ (a) plasma concentrations are also contradictory. For example, Bruin et al. and Kung et al. as well as Erem et al. observed decreased plasma concentrations in patients with manifest hyperthyroidism compared to healthy euthyroid controls as well as hypothyroid patients, respectively $[147,154,155]$. In addition, Erem et al. observed negative correlations between the plasma concentrations of thyroxine and $\operatorname{Lp}(\mathrm{a})$ in their patients [154]. On the other hand, Lee et al. found no such decrease of the $\mathrm{Lp}$ (a) plasma concentrations in patients with manifest or subclinical hyperthyroidism [149]. In principle, the discrepant results of these studies can be explained by several theories. Firstly, the results of the patient studies might be biased by the small number of participants because the Lp(a) plasma concentrations are affected by a number of other factors (e.g. Lp(a) genotype) which were often not considered in these studies and the weight of these influence factors is higher in smaller studies than in larger ones [143, $156,157]$. Another possible explanation is the intensity of the thyroid disease. For example, subclinical hypothyroidism has only a mild effect on lipid metabolism (including Lp(a)), whereas the effect of manifest hypothyroidism is much stronger [145].

Another aspect is the effect of treatment on the plasma concentration of $\mathrm{Lp}(\mathrm{a})$. However, the results of studies investigating the effect of hormone supplementation (triiodothyronine (T3) and thyroxine (T4)) are also contradictory. For example Dullaart et al. observed a decrease of $L p(a)$ plasma concentrations in their patients after supplementation of T3 [142]. Decreases were also observed in several studies of patients with hypothyroidism caused by other diseases supplemented with T3 or T4 [144, $146-148,158,159]$. In one of these studies the therapy induced decrease depended on the initial plasma concentration of $\mathrm{Lp}(\mathrm{a})$ and was more pronounced in patients with $\mathrm{Lp}$ (a) concentrations $>30 \mathrm{mg} / \mathrm{dl}$ [146]. However, other investigators found no effect of hormone supplementation on $\mathrm{Lp}$ (a) plasma concentrations in patients with manifest hypothyroidism $[157,160,161]$. Inconsistent data were also reported in studies investigating patients with subclinical hypothyroidism. Some investigators found a decrease of Lp(a) plasma concentrations in these patients after supplementation [152, 153] whereas no such effect was observed in the majority of studies [148, 150, 160-162]. A possible explanation for the conflicting results is that not all of the patients included in these studies suffered from increased $L p(a)$ plasma concentrations $[152,153]$ and the effect of T4 supplementation is more pronounced in patients with initially stronger increased concentrations of $\mathrm{Lp}(\mathrm{a})$ [152]. Furthermore, the lack of an effect in patients with subclinical hypothyroidism compared to patients with manifest hypothyroidism underlines the difference between both dysfunctions of the thyroid gland also affecting lipid metabolism [145]. In contrast to the large number of studies investigating the effect of hormone supplementation in patients with subclinical or manifest hypothyroidism only a minor number of studies dealt with the effect of thyrostatic treatment (thyrostatic drugs or radioactive iodine) on $\mathrm{Lp}(\mathrm{a})$ plasma concentrations in patients with hyperthyroidism (e.g. patients with Basedow's disease). However, these studies observed an increase of $\mathrm{Lp}$ (a) plasma concentrations which was independent from the variations found for LDL in plasma [144, 147, 155, 159].

\section{Androgens}

Experimental studies performed in transgenic mice demonstrated a regulation of the apo(a) gene by sexual steroids and a downregulation by testosterone [163]. In humans endogenous testosterone has no relevant effect on Lp(a) plasma concentration [164-168]. In contrast, administration of testosterone or other anabolic compounds affects a large number of parameters including those of atherogenesis and lipid metabolism [169-171]. For example, Lp(a) plasma concentrations decrease in males [167, 170, 172-174] and oophorectomized females [175] after administration of testosterone. The decrease is more pronounced in individuals with higher initial $L p(a)$ concentrations but not dependent from the Lp(a) phenotype [167]. Even other synthetic anabolics (e.g. danazol, nandrolonedecanoate, stanozolol) administered in both genders for different clinical indications (e.g. bodybuilding, endometriosis, hemodialysis, postmenopausal osteoporosis) caused changes in plasma lipoprotein patterns and a decrease of $\mathrm{Lp}$ (a) plasma concentration depending in some studies on the initial plasma concentrations [176-180]. Dehydroepiandrostenedione (DHEA), another anabolic steroid is physiologically synthesized and metabolized via androstenedione into testosterone, estradiol and estrone. In males and postmenopausal females plasma concentrations of DHEA and $\operatorname{Lp}(\mathrm{a})$ are negatively correlated $[181,182]$. In postmenopausal females [183] but not in males [182] administration of DHEA causes a mild decrease of $L p(a)$ plasma concentrations. In contrast, orchiectomy is followed by an increase of the $\mathrm{Lp}(\mathrm{a})$ plasma concentration due to the decrease of the plasma testosterone concentration [173]. Similar increases were observed in the majority of studies performed in healthy young males and males with prostate carcinoma treated with gonadotropin-releasing hormone $(\mathrm{GnRH})$ agonists (e.g. buserelin, goserelin, triptorelin) or antagonists (e.g. cetrorelix) because these substances inhibit testosterone synthesis [178, 184-186]. In one of these studies the intensity of the therapeutic effect on the Lp(a) plasma concentration depended on the initial $\mathrm{Lp}$ (a) concentration prior to the administration of the compound [186]. Last not least, even administration of antiandrogens (e.g. finasteride, a $5 \alpha$-reductase inhibitor) is followed by an increase of the Lp(a) concentration in plasma [187].

\section{Estrogens and Gestagens}

Beside their typical effects in females estrogens and gestagens have an antiatherogenic effect which is in part based on variations of lipid metabolism including $L p(a)$ $[188,189]$. A number of studies demonstrated that $L p(a)$ plasma concentrations in premenopausal females with normal menstrual cycles are not or only slightly affected by the cyclic hormonal changes [190-193]. However, stimulation with follicle stimulating hormone (FSH) in the luteal phase causes a progesterone dependent increase of the $\mathrm{Lp}$ (a) plasma concentration. The increase is temporary if there is no pregnancy and persists in pregnant females [191, 193]. Further studies demonstrated that even in males there is no significant correlation between plasma concentrations of estrogen and $\mathrm{Lp}(\mathrm{a})[164,166,167]$. 
In cases of a iatrogenic menopause in premenopausal females (e.g. by surgical measures [194, 195] or chemotherapeutics [196]) an increase of $\mathrm{Lp}(\mathrm{a})$ plasma concentration was observed beside other changes of lipid metabolism. However, an administration of estrogens causes a reversion of the observed changes including those of $L p(a)$ [175, 194, 195, 197]. Only in a small subset of studies no changes of $\mathrm{Lp}$ (a) plasma concentrations were observed in oophorectomized females vs. healthy controls and oophorectomized females before and after estrogen therapy, respectively [198, 199]. Similar results were obtained even in males after orchidectomy. In the latter administration of estrogens abolished or reversed the increase of $\mathrm{Lp}$ (a) plasma concentration caused by the testosterone deficiency [200, 201]. On the other hand, Berglund et al. observed no reduction of $L p(a)$ plasma concentration in their study also performed in orchidectomized males [173]. However, it is likely that the contradictory results are caused by different ways of drug administration because estrogens after oral application are subject of an intensive first pass metabolism whereas estrogens given parenterally by intramuscular injection or by transdermal application are not [173, 202]. Interestingly, comparison of the therapeutic effects of estrogen and testosterone demonstrates that both hormones cause a decrease of $\mathrm{Lp}(\mathrm{a})$ plasma concentration whereas many other physiological effects are contrary. Last not least, one more aspect of hormonal regulation of $\mathrm{Lp}$ (a) plasma concentration in females should be noted. Individuals suffering from polycystic ovary syndrome (PCOS; formerly Stein-Leventhal syndrome) are characterized by infertility, obesity and dyslipidemia including increased plasma concentrations of $\mathrm{Lp}(\mathrm{a})$. Investigations of Velazquez et al. and Yilmaz et al. indicated that females with PCOS have elevated Lp(a) plasma concentrations which can be lowered by administration of metformin, a substance given for treatment of diabetes mellitus type 2 [203, 204].

The natural menopause is also characterized by an increase of the $\mathrm{Lp}(\mathrm{a})$ concentrations in plasma when compared to the premenopausal values [205]. Together with other changes of plasma lipid parameters this increase correlates with an increased risk for the development of atherosclerotic diseases [206, 207, 208]. Administration of sexual steroids (e.g. estrogens, estrogens combined with gestagens) in postmenopausal females (so-called hormone replacement therapy; HRT) as well as estrogen receptor modulating substances (e.g. raloxifene) cause changes in plasma lipoprotein patterns including a decrease of $\mathrm{Lp}(\mathrm{a})$. However, the results of these studies regarding the effect of estrogens differ because the pharmacological effect strongly depends on the mode of application (transcutaneous, intramuscular, oral) and consecutively on the intensity of the hepatic first pass effect [206-219]. The decrease of Lp(a) plasma concentrations due to hormonal replacement therapy was more pronounced in individuals with high initial concentrations than in those with lower ones [206, 207, 211, 218].

Antiestrogens (e.g. tamoxifen and toremifene) which are used in the therapy of postmenopausal females with breast carcinoma oppose many of the pharmacological effects of estrogens. Interestingly, administration of these compounds beside the desired therapeutic effects cause a shift in the plasma lipoprotein status towards a lower atherogenicity including a decrease of the plasma Lp(a) concentration [217, 220-225]. However, in one of these studies an additional effect of the phenotype of apolipoprotein $E$ (apoE) has been described [222]. In contrast, another substance used for treatment of females with breast cancer, the aromatase inhibitor letrozole, has obviously no effect on the plasma concentration of $\mathrm{Lp}(\mathrm{a})$ [226].

\section{Other Hormones}

The effect of several other hormones on Lp(a) plasma concentrations has also been investigated. For example, administration of corticotropin or its analogues (e.g. synacthene) causes a significant decrease of $\mathrm{Lp}(\mathrm{a})$ plasma concentrations in healthy individuals, patients with terminal renal failure and hemodialysis as well as individuals after kidney transplantation [2, 227-229].

Insulin has no direct effect on $\mathrm{Lp}(\mathrm{a})$ plasma concentrations [13]. Compared to healthy individuals patients with diabetes mellitus type 1 have only small changes of $\mathrm{Lp}$ (a) plasma concentrations. In consequence, an improved metabolic control in these patients by an optimized insulin therapy is not followed by a relevant change of $\mathrm{Lp}(\mathrm{a})$ plasma concentration $[2,13]$. In contrast, patients with diabetes mellitus type 2 are characterized by significantly higher Lp(a) plasma concentrations than healthy individuals. However, it is likely that this is a secondary effect, because these patients have an impaired renal function and in consequence a lower rate of secreted apo(a) fragments in urine $[2,230]$.

Two other hormones, human growth hormone (HGH) and insulin-like growth factor (IGF-1), have an antagonistic effect on Lp(a) plasma concentration [2, 231]. Administration of growth hormone, e.g. in children with impaired growth and adults with HGH-deficiency, is followed by a significant increase of $\mathrm{Lp}(\mathrm{a})$ plasma concentration [2, 232-235] which is not dependent on the Lp(a) phenotype [234]. On the other hand, application of IGF-1, e.g. in animals or patients with Laron syndrome (growth hormone resistance) causes a decrease of $\mathrm{Lp}(\mathrm{a})$ plasma concentration [236, 237] which might be caused by an increased degradation of $\mathrm{Lp}(\mathrm{a})$ [237]. Furthermore, normalization of the IGF-1 plasma concentration by the HGH-receptor antagonist pegvisomant is followed by a decrease of $\mathrm{Lp}$ (a) plasma concentrations in acromegaly patients [238].

\section{INFLUENCE OF NUTRITION AND LIFE-STYLE ON LP(a) PLASMA CONCENTRATIONS}

The individual life style plays an important role for the development of cardiovascular diseases. In contrast to the large number of other risk factors which cannot be modified (e.g. gender, age) the impact of life style related factors (e.g. nutrition, sports, smoking) can be modified (e.g. cessation of smoking, changes in nutrition, sports). A number of frequent life style factors and their effect on the plasma concentration of $\mathrm{Lp}(\mathrm{a})$ is described below.

\section{Alcohol}

A number of studies has investigated the effect of ethanol consumption on the plasma concentration of $\mathrm{Lp}(\mathrm{a})$. Chronic alcohol consumption causes a strong decrease of the plasma 
concentration (up to $60 \%$ ) which is dose dependent and shows no dependency on the size polymorphism of $\mathrm{Lp}(\mathrm{a})$ [239-241]. Vice versa after end or even after reduction of the alcohol consumption an increase of the $\mathrm{Lp}(\mathrm{a})$ plasma concentration has been observed [242-249]. However, the mechanism causing the alcohol dependent variation of $\mathrm{Lp}(\mathrm{a})$ plasma concentration has not been elucidated. It is discussed that the insulin-like growth factor-1 (IGF-1) binding protein is involved in this regulatory process $[2,247]$.

\section{Nutrition}

Moderate diets have no relevant effect on the plasma concentration of $\mathrm{Lp}(\mathrm{a})$ [250]. However, an effect of nutrition on the plasma concentration of $\operatorname{Lp}(\mathrm{a})$ has been described in a number of studies. For example, trans-fatty acids, e.g. elaidic acid which is found in fritted food in a relevant concentration, causes an increase of the $\mathrm{Lp}(\mathrm{a})$ plasma concentration between $25 \%$ and $50 \%$ which is more pronounced in individuals with higher initial plasma concentrations [10, 251-255]. On the other hand a protective effect of unsaturated or polyunsaturated fatty acids as well as fat modified food caused by lowering of plasma $\mathrm{Lp}(\mathrm{a})$ concentration is discussed [10, 256-260].

\section{Cigarette Smoking}

Cigarette smoking is an important risk factor for the development of cardiovascular diseases and smoking dependent changes of plasma lipoprotein patterns have been described in a large number of studies [261]. A number of studies investigated the effect of cigarette smoking on $\mathrm{Lp}(\mathrm{a})$ plasma concentrations. In some of these studies lower concentrations of $\mathrm{Lp}(\mathrm{a})$ were observed in plasma of smokers compared to nonsmokers [2, 262-265]. However, in other studies no effect of smoking was found [266, 267] or smokers had even higher plasma concentrations of $\mathrm{Lp}(\mathrm{a})$ than nonsmokers [268]. In summary, the majority of results indicate that cigarette smoking causes a reduction of $L p(a)$ plasma concentration. However this potentially protective effect has no clinical relevance because it is opposed by a very large number of harmful effects also caused by cigarette smoking [262].

\section{Physical Exercise and Sports}

A large number of studies has described the protective effect of physical exercise and sports on the risk for the development of cardiovascular diseases. However, the results of studies investigating the effect of both parameters on the plasma concentration of $\mathrm{Lp}$ (a) are conflicting. Some studies demonstrated a decrease or no relevant change of plasma $\mathrm{Lp}$ (a) concentrations due to physical exercise and sports [140, 250, 268-273]. On the other hand, other often older studies observed a mild increase of the plasma $L p(a)$ concentration without further clinical relevance [267, 274276].

\section{THERAPEUTIC INFLUENCE ON LP(a) CONCEN- TRATIONS}

A large number of studies has investigated the effect of various pharmacological substances and apheresis methods on $\mathrm{Lp}$ (a) plasma concentrations. These are described in the following in more detail insofar as they have relevance for the control of lipid metabolism. Further compounds like sexual steroids, glucocorticoids and thyroid hormones have been discussed before.

Administration of niacin or nicotinic acid has a positive (i. e. antiatherogenic) effect on several parameters of lipid metabolism and additionally causes a significant decrease of Lp(a) plasma concentrations. In addition, treatment with nicotinic acid can be combined with the treatment by other pharmacological substances for therapy of hyperlipidemia (e.g. gemfibrozil and inhibitors of the enzyme hydroxymethylglutaryl-CoA-reductase (HMG-CoA reductase, socalled statins) [277-287] (Table 1).

Fibrates (including gemfibrozil) are another group often used for the treatment of dyslipidemia. Substances of these group cause a reduction of mRNA for $\mathrm{Lp}(\mathrm{a})$ in vitro [288]. However, the results of in vivo studies are conflicting and demonstrate only a slight therapeutic effect regarding the effect on Lp(a) [287, 289-293] (Table 1).

Table 1. Effect of Lipid Lowering Drugs on the Plasma Concentration of $\operatorname{Lp}(\mathbf{a})$

\begin{tabular}{|l|l|}
\hline Compound & Effect \\
\hline \hline Niacin, nicotinic acid & $\downarrow$ \\
\hline Fibrates & $(\downarrow)$ \\
\hline Apheresis & $\downarrow \downarrow$ \\
\hline Statins & Mostly none \\
\hline Resins & Mostly none \\
\hline Thiazolidinedione & $(\downarrow)$ \\
\hline $\begin{array}{l}\text { Fish oil, } \omega 3 \text { - or } \omega 6 \text {-fatty acids, olive oil, rape oil, soy } \\
\text { oil, polyunsaturated fatty acids and partially hydrated } \\
\text { fatty acids }\end{array}$ & Mostly none \\
\hline
\end{tabular}

A very effective therapeutic approach for treatment of hypercholesterolemia characterized by high plasma concentrations of low density lipoproteins (LDL) and high concentrations of $\mathrm{Lp}(\mathrm{a})$ are different techniques of lipid apheresis. However, disadvantages of these techniques are their invasive character (like dialysis) and the required frequency of treatment (at least every two weeks) causing low compliance and high therapeutic costs. A large number of apheresis techniques has been described which is based on plasma separation (Lipid filtration (DIAMED Medizintechnik GmbH); immunoadsorption (TherasorbLDL, Miltenyi Biotec $\mathrm{GmbH}$ ); dextran sulphate adsorption (Liposorber LA 15, Kaneka); heparin-induced extracorporeal LDL-precipitation (H.E.L.P., B. Braun Medizintechnologie $\mathrm{GmbH})$ ) or methods performed in full blood (direct adsorption of lipoproteins (DALI ${ }^{\circledR}$, Fresenius Medical Care $\mathrm{D}-\mathrm{GmbH}$ ); adsorption on dextran sulfate (Liposorber D, Kaneka, DIAMED Medizintechnik GmbH)). All methods have been primarily developed for treatment of high plasma LDL concentrations. However, because of the large structural similarity of LDL and Lp(a) the efficiency of these methods on both lipoproteins is very similar. In detail, dependent on the treated plasma or blood volume concentrations of $\mathrm{Lp}(\mathrm{a})$ and LDL are lowered $50 \%-74 \%$ 
and $>60 \%$ at each therapy and even other hemorheological parameters (e.g. fibrinogen, viscosity) are positively influenced [294-310] (Table 1).

In contrast, statins which play a central role in the treatment of hypercholesterolemia, despite their strong effect on LDL have no relevant effect or - in some studies - cause an increase of $\mathrm{Lp}(\mathrm{a})$ plasma concentrations if they are administered alone [209, 215, 289, 311-319]. Only few studies describe a decrease of $\mathrm{Lp}$ (a) plasma concentrations under statin therapy [320, 321] (Table 1). The same takes place for substances inhibiting intestinal cholesterol absorption (e.g. resins) which are sometimes combined with other lipid lowering substances, especially statins, to enhance their cholesterol lowering effect [312, 320] (Table 1).

Beside these substances which have been introduced into clinical therapy since many years there are others which have been recently introduced into therapy or which are up to now under investigation [278]. An interesting group are compounds acting via modulation of the peroxisome proliferator activated receptor (PPAR) from which three different subtypes ( $\alpha, \gamma$ and $\delta$ ) have been described [278]. This pharmaceutical group includes thiazolidinediones (socalled glitazones, e.g. pioglitazone, rosiglitazone, troglitazone) introduced for oral treatment of diabetes mellitus type 2 . Studies performed in these patients revealed positive effects also on plasma lipoprotein patterns including a decrease of the Lp(a) concentration [322, 323] (Table 1).

The effects of different fatty acids (e.g. fish oil, $\omega 3$ - or $\omega 6$-fatty acids, olive oil, rape oil, soy oil, polyunsaturated fatty acids and partially hydrated fatty acids) on plasma concentrations were subject of several studies performed in very different population and patient groups. However, the results obtained in these studies are very conflicting. In some studies an increase or a decrease of $\mathrm{Lp}(\mathrm{a})$ plasma concentration was observed whereas other studies failed to show any effect [257, 258, 260, 324-328].

Some more studies investigated the effect of other compounds like carnitine [317, 329-331], coenzyme $\mathrm{Q}_{10}$ [332, 333] or aspirin [334, 335] on plasma $L p(a)$ and also showed conflicting outcomes.

\section{SUMMARY}

Literature data demonstrate that $\mathrm{Lp}(\mathrm{a})$ plays a relevant role as a risk factor for atherosclerosis and thrombosis. However, its physiological effect is far beyond this as $\mathrm{Lp}(\mathrm{a})$ seems also to play a role in angiogenesis as well as tumor development and metastasis. Plasma concentrations of $\mathrm{Lp}(\mathrm{a})$ are genetically determined but also can be modulated by various diseases, life style factors and drugs. Our review summarizes the effects of these parameters on $\mathrm{Lp}$ (a) plasma concentration and demonstrates that for some of them conflicting data have been published. However, the effects of some other parameters on $\mathrm{Lp}(\mathrm{a})$ plasma concentration is more confirmed and therefore should be considered in medical diagnostics and treatment.

\section{REFERENCES}

[1] Berg, K. A new serum type system in man: the LP system. Acta Pathol. Scand., 1963, 59, 369-382.
[2] Kostner, K.M.; Kostner, G.M. Therapy of Hyper-Lp(a). Handb. Exp. Pharmacol., 2005, 170, 519-536.

[3] Dahlen, G.H.; Guyton, J.R.; Attar, M.; Farmer, J.A.; Kautz, J.A.; Gotto, A.M. Association of levels of lipoprotein Lp(a), plasma lipids, and other lipoproteins with coronary artery disease documented by angiography. Circulation, 1986, 74, 758-765.

[4] Jones, G.T.; van Rij, A.M.; Cole, J.; Williams, M.J.; Bateman, E.H.; Marcovina, S.M.; Deng, M.; McCormick, S.P. Plasma lipoprotein(a) indicates risk for 4 distinct forms of vascular disease. Clin. Chem., 2007, 53, 679-685.

[5] Kostner, G.M.; Avogaro, P.; Cazzolato, G.; Marth, E.; Bittolo-Bon, G.; Quinici, G.B. Lipoprotein (a) and the risk for myocardial infarction. Atherosclerosis, 1981, 38, 51-61.

[6] Terres, W.; Tatsis, E.; Pfalzer, B.; Beil, F.U.; Beisiegel, U.; Hamm, C.W. Rapid angiographic progression of coronary artery disease in patients with elevated lipoprotein(a). Circulation, 1995, 91, 948950.

[7] Kostner, G.M.; Krempler, F. Lipoprotein(a). Curr. Opin. Lipidol., 1992, 3, 279-284.

[8] Craig, W.Y.; Neveux, L.M.; Palomaki, G.E.; Cleveland, M.M.; Haddow, J.E. Lipoprotein(a) as a risk factor for ischemic heart disease: Metaanalysis of prospective studies. Clin. Chem., 1998, 44, 2301-2306.

[9] Danesh, J.; Collins, R.; Peto, R. Lipoprotein(a) and coronary heart disease. Meta-Analysis of prospective studies. Circulation, 2000, 102, 1082-1085.

[10] Enas, E.A.; Chacko, V.; Senthilkumar, A.; Puthumana, N.; Mohan, V. Elevated lipoprotein(a) - A genetic risk factor for premature vascular disease in people with and without standard risk factors: a review. Dis. Mon., 2006, 52, 5-50.

[11] The Emerging Risk Factors Collaboration; Erqou, S.; Kaptoge, S.; Perry, P.L.; Di Angelantonio, E.; Thompson, A.; White, I.R.; Marcovina, S.M.; Collins, R.; Thompson, S.G.; Danesh, J. Lipoprotein(a) concentration and the risk of coronary heart disease, stroke, and nonvascular mortality. JAMA, 2009, 302, 412-423.

[12] White, A.L.; Lanford, R.E. Cell surface assembly of lipoprotein(a) in primary cultures of baboon hepatocytes. J. Biol. Chem., 1994, 269, 28716-28723.

[13] Kostner, G.M. Lipoprotein(a): metabolismus und beeinflussung des plasmaspiegels. J. Kardiol., 2002, 9, 321-324.

[14] Krempler, F.; Kostner, G.M.; Bolzano, K.; Sandhofer, F. Turnover of lipoprotein (a) in man. J. Clin. Invest., 1980, 65, 1483-1490.

[15] Kronenberg, F.; Utermann, G.; Dieplinger, H. Lipoprotein(a) in renal disease. Am. J. Kidn. Dis., 1996, 27, 1-25.

[16] Thiery, J.; Ivandic, B.; Bahlmann, G.; Walli, A.K.; Seidel D. Hyperlipoprotein(a)aemia in nephrotic syndrome. Eur. J. Clin. Invest., 1996, 26, 316-321.

[17] Leischik, R.; Dworrak, B.; Gülker, H. Lipoprotein(a): Koronare Herzerkrankung - klinische bedeutung und therapieoptionen. Dtsch. Med. Wochenschr., 2005, 130, 2518-2523.

[18] McLean, J.W.; Tomlinson, J.E.; Kuang, W.J.; Eaton, D.L.; Chen, E.Y.; Fless, G.M.; Scanu, A.M.; Lawn, R.M. cDNA sequence of human apolipoprotein(a) is homologous to plasminogen. Nature, 1987, 330, 132-137.

[19] Frank, S.; Kostner, G.M. The role of apo-(a) kringle-IVs in the assembly of lipoprotein-(a). Protein Eng., 1997, 10, 291-298.

[20] Frank, S.; Durovic, S.; Kostner, G.M. Structural requirements of apo-a for the lipoprotein-a assembly. Biochem J., 1994, 304, 27-30.

[21] Gries, A.; Nimpf, J.; Nimpf, M.; Wurm, H.; Kostner, G.M. Free and apoB-associated Lp(a) specific protein in human serum. Clin. Chim. Acta, 1987, 164, 93-100.

[22] Frank, S.; Hrzenjak, A.; Blaschitz, A.; Dohr, G.; Kostner, G.M. Role of various tissues in apo(a) fragmentation and excretion of fragments by the kidney. Eur. J. Clin. Invest., 2001, 31, 504-512.

[23] Kostner, K.M.; Maurer, G.; Huber, K.; Stefenelli, T.; Dieplinger, H.; Steyrer, E.; Kostner, G.M. Urinary excretion of apo(a) fragments. Role in apo(a) catabolism. Arterioscler. Thromb. Vasc. Biol., 1996, 16, 905-911.

[24] Hrzenjak, A.; Frank, S.; Wo, X.; Zhou, Y.; van Berkel, T.; Kostner, G.M. Galactose-specific asialoglycoprotein receptor is involved in lipoprotein (a) catabolism. Biochem. J., 2003, 376, 765-771.

[25] Lackner, C.; Cohen, J.C.; Hobbs, H.H. Molecular definition of the extreme size polymorphism in apolipoprotein(a). Hum. Mol. Genet., 1993, 2, 993-940.

[26] Utermann, G. The mysteries of lipoprotein(a). Science, 1989, 246, 904-910. 
[27] Kostner, G.M.; Gries, A.; Pometta, M.; Molinari, E.; Pichler, P.; Aicher, H. Immunochemical determination of lipoprotein $\mathrm{Lp}(\mathrm{a})$ : Comparison of Laurell electrophoresis and ELISA. Clin. Chim. Acta, 1990, 188, 187-192.

[28] Puckey, L.; Knight, B. Dietary and genetic interactions in the regulation of plasma lipoprotein(a). Curr. Opin. Lipidol., 1999, 10, 35-40.

[29] Kraft, H.G.; Lingenhel, A.; Pang, R.W.C; Delport, R.; Trommsdorf, M.; Vermaak, H.; Janus, E.D.; Utermann, G. Frequency distributions of apolipoprotein(a) kringle IV repeat alleles and their effects on lipoprotein(a) levels in Caucasian, Asian, and African populations: the distribution of null alleles is non-random. Eur. J. Hum. Genet., 1996, 4, 74-87.

[30] Utermann, G.; Menzel, H.J.; Kraft, H.G.; Duba, H.C.; Kemmler, H.G.; Seitz, C. Lp(a) glycoprotein phenotypes. Inheritance and relation to $\mathrm{Lp}(\mathrm{a})$-lipoprotein concentrations in plasma. J. Clin. Invest., 1987, 80, 458-465.

[31] White, A.L.; Hixson, J.E.; Rainwater, D.L.; Lanford, R.E. Molecular basis for "null" lipoprotein(a) phenotypes and the influence of apolipoprotein(a) size on plasma lipoprotein(a) level in the baboon. J. Biol. Chem., 1994, 269, 9060-9066.

[32] White, A.L.; Guerra, B.; Wang, J.; Lanford, R.E. Presecretory degradation of apolipoprotein (a) is mediated by the proteasome pathway. J. Lipid. Res., 1999, 40, 275-286.

[33] Leischik, R.; Dworrak, B. Lipoprotein(a): Bedeutung für das fibrinolytische system und thromboembolische komplikationen. Herz, 2006, 31, 144-152.

[34] Siekmeier, R.; Scharnagl, H.; Kostner, G.M., Grammer, T.; Stojacovic, T., März, W. Lipoprotein(a) - structure, epidemiology, function and diagnostics of a cardiovascular risk marker. Open Clin. Chem. J., 2008, 1, 79-91.

[35] Fan, J.; Sun, H.; Unoki, H.; Shiomi, M.; Watanabe, T. Enhanced atherosclerosis in Lp(a) WHHL transgenic rabbits. Ann. N.Y. Acad. Sci., 2001, 947, 362-365.

[36] Ichikawa, T.; Unoki, H.; Sun, H.; Shimoyamada, H.; Marcovina, S.; Shikama, H.; Watanabe, T.; Fan, J. Lipoprotein(a) promotes smooth muscle cell proliferation and dedifferentiation in atherosclerotic lesions of human apo(a) transgenic rabbits. Am. J. Pathol., 2002, 160, 227-236.

[37] Sun, H.; Unoki, H.; Wang, X.; Liang, J.; Ichikawa, T.; Arai, Y.; Shiomi, M.; Marcovina, S.M.; Watanabe, T.; Fan, J. Lipoprotein(a) enhances advanced atherosclerosis and vascular calcification in WHHL transgenic rabbits expressing human apolipoprotein(a). $J$. Biol. Chem., 2002, 277, 47486-47492.

[38] Bihari-Varga, M.; Gruber, E.; Rotheneder, M.; Zechner, R.; Kostner, G.M. Interaction of lipoprotein $\mathrm{Lp}$ (a) and low density lipoprotein with glycosaminoglycans from human aorta. Arteriosclerosis, 1988, 8, 851-857.

[39] D’Angelo, A.; Geroldi, D.; Hancock, M.A.; Valtulina, V.; Cornaglia, A.I.; Spencer, C.A.; Emanuele, E.; Calligaro, A.; Koschinsky, M.L.; Speziale, P.; Visai. L. The apolipoprotein(a) component of lipoprotein(a) mediates binding to laminin: Contribution to selective retention of lipoprotein(a) in atherosclerotic lesions. Biochim. Biophys. Acta, 2005, 1687, 1-10.

[40] Dahlen, G.; Ericson, C.; Berg, K. In vitro studies of the interaction of isolated $\mathrm{Lp}$ (a) lipoprotein and other serum lipoproteins with glycosaminoglycans. Clin. Genet., 1978, 14, 36-42.

[41] Poon, M.; Zhang, X.; Dunsky, K.G.; Taubman, M.B.; Harpel, P.C. Apolipoprotein(a) induces monocyte chemotactic activity in human vascular endothelial cells. Circulation, 1997, 96, 2514-2519.

[42] Sotiriou, S.N.; Orlova, V.V.; Al-Fakhri, N.; Ihanus, E.; Economopoulou, M.; Isermann, B.; Bdeir, K.; Nawroth, P.P.; Preissner, K.T.; Gahmberg, C.G.; Koschinsky, M.L.; Chavakis T. Lipoprotein(a) in atherosclerotic plaques recruits inflammatory cells through interaction with Mac-1 integrin. FASEB J., 2006, 20, 559-561.

[43] Fujisawa, M.; Haramaki, R.; Miyazaki, H.; Imaizumi, T.; Okuda, S. Role of lipoprotein (a) and TGF- $\beta 1$ in atherosclerosis of hemodialysis patients. J. Am. Soc. Nephrol., 2000, 11, 1889-1895.

[44] Grainger, D.J.; Kirschenlohr, H.L.; Metcalfe, J.C.; Weissberg, P.L.; Wade, D.P.; Lawn, R.M. Proliferation of human smooth muscle cells promoted by lipoprotein(a). Science, 1993, 260, 1655-1658.

[45] Ross, R. The pathogenesis of atherosclerosis: a perspective for the 1990s. Nature, 1993, 362, 801-809.

[46] Ross, R. Atherosclerosis - an inflammatory disease. N. Engl. J. Med., 1999, 340, 115-126.
[47] Grainger, D.J.; Kemp, P.R.; Liu, A.C.; Lawn, R.M.; Metcalfe, J.C. Activation of transforming growth factor-beta is inhibited in transgenic apolipoprotein(a) mice. Nature, 1994, 370, 460-462.

[48] Kojima, S.; Harpel, P.C.; Rifkin, D.B. Lipoprotein (a) inhibits the generation of transforming growth factor beta: An endogenous inhibitor of smooth muscle cell migration. J. Cell Biol., 1991, 113, 1439-1445.

[49] von Eckardstein, A.; Schulte, H.; Cullen, P.; Assmann, G. Lipoprotein(a) further increases the risk of coronary events in men with high global cardiovascular risk. J. Am. Coll. Cardiol., 2001, 37, 434-439.

[50] Cantin, B.; Despres, J.P.; Lamarche, B.; Moorjani, S.; Lupien, P.J.; Bogaty, P.; Bergeron, J.; Dagenais, J.R. Association of fibrinogen and lipoprotein(a) as a coronary heart disease risk factor in men (The Quebec Cardiovascular Study). Am. J. Cardiol., 2002, 89, 662-666.

[51] Cobbaert, C.; Jukema, J.W.; Zwinderman, A.H.; Withagen, A.J.A.M.; Lindemans, J.; Bruschke, A.V.G.; on behalf of the Regression Growth Evaluation Statin Study (REGRESS) Study Group. Modulation of lipoprotein(a) atherogenicity by high density lipoprotein cholesterol levels in middle-aged men with symptomatic coronary artery disease and normal to moderately elevated serum cholesterol. J. Am. Coll. Cardiol., 1997, 30, 14911499 .

[52] Ridker, P.M.; Hennekens, C.A.; Stampfer, M.J. A prospective study of lipoprotein(a) and the risk of myocardial infarction. JAMA, 1993, 270, 2195-2199.

[53] Harpel, P.C.; Hermann, A.; Zhang, X.; Ostfeld, I.; Borth, W Lipoprotein(a), plasmin modulation, and atherogenesis. Thromb. Haemost., 1995, 74, 382-386.

[54] Harpel, P.C.; Gordon, B.R.; Parker, T.S. Plasmin catalyzes binding of lipoprotein (a) to immobilized fibrinogen and fibrin. Proc. Natl. Acad. Sci. USA, 1989, 86, 3847-3851.

[55] Loscalzo, J.; Weinfeld, M.; Fless, G.M.; Scanu, A.M. Lipoprotein(a), fibrin binding, and plasminogen activation. Arteriosclerosis, 1990, 10, 240-245.

[56] Harpel, P.C.; Chang, V.T.; Borth, W. Homocysteine and other sulfhydryl compounds enhance the binding of lipoprotein(a) to fibrin: A potential biochemical link between thrombosis, atherogenesis, and sulfhydryl compound metabolism. Proc. Natl. Acad. Sci. USA, 1992, 89, 10193-10197.

[57] Nachman, R.L. Thrombosis and atherogenesis: molecular connections. Blood, 1992, 79, 1897-1906.

[58] Fleury, V.; Lijnen, H.R.; Angles-Cano, E. Mechanism of the enhanced intrinsic activity of single-chain urokinase-type plasminogen activator during ongoing fibrinolysis. J. Biol. Chem., 1993, 268, 18554-18559.

[59] Harpel, P.C.; Chang, T.S.; Verderber, E. Tissue plasminogen activator and urokinase mediate the binding of Glu-plasminogen to plasma fibrin I. Evidence for new binding sites in plasmindegraded fibrin I. J. Biol. Chem., 1985, 260, 4432-4440.

[60] Hoylaerts, M.; Rijken, D.C.; Lijnen, H.R.; Collen, D. Kinetics of the activation of plasminogen by human tissue plasminogen activator. Role of fibrin. J. Biol. Chem., 1982, 257, 2912-2919.

[61] Lijnen, H.R.; Bachmann, F.; Collen, D.; Ellis, V.; Pannekoek, H.; Rijken, D.C.; Thorsen, S. Mechanism of plasminogen activation. $J$. Intern. Med., 1994, 236, 415-424.

[62] Suenson, E.; Lutzen, O.; Thorsen, S. Initial plasmin-degradation of fibrin as the basis of a positive feed-back mechanism in fibrinolysis. Eur. J. Biochem. 1984, 140, 513-522.

[63] Vali, Z.; Patthy, L. Location of the intermediate and high affinity $\omega$-aminocarboxylic acid-binding sites in human plasminogen. $J$. Biol. Chem., 1982, 257, 2104-2110.

[64] Hajjar, K.A.; Gavish, D.; Breslow, J.L.; Nachman, R.L. Lipoprotein(a) modulation of endothelial cell surface fibrinolysis and its potential role in atherosclerosis. Nature, 1989, 339, 303305 .

[65] Miles, L.A.; Fless, G.M.; Levin, E.G.; Scanu, A.M.; Plow, E.F. A potential basis for the thrombotic risks associated with lipoprotein(a). Nature, 1989, 339, 301-303.

[66] Rouy, D.; Grailhe, P.; Nigon, F.; Chapman, J.; Angles-Cano, E. Lipoprotein(a) impairs generation of plasmin by fibrin-bound tissue-type plasminogen activator. In vitro studies in a plasma milieu. Arterioscler. Thromb. 1991, 11, 629-638.

[67] Buechler, C.; Ullrich, H.; Ritter, M.; Porsch-Oezcueruemez, M.; Lackner, K.J.; Barlage, S.; Friedrich, S.O.; Kostner, G.M.; Schmitz, 
G. Lipoprotein (a) up-regulates the expression of the plasminogen activator inhibitor 2 in human blood monocytes. Blood, 2001, 97, 981-986.

[68] Bajaj, M.; Kuppuswamy, M.; Saito, H.; Spitzer, S.G.; Bajaj, S.P. Cultured normal human hepatocytes do not synthesize lipoproteinassociated coagulation inhibitor: Evidence that endothelium is the principal site of its synthesis. Proc. Natl. Acad. Sci. USA, 1990, 87, 8869-8873.

[69] Broze, G.; Warren, L; Novotny, W.F.; Higuchi, D.A.; Girard, J.J.; Miletich, J.P. The lipoprotein-associated coagulation inhibitor that inhibits the factor VII-tissue factor complex also inhibits factor Xa: Insight into its possible mechanism of action. Blood, 1988, 71, 335343.

[70] Lindhout, T.; Blezer, R.; Schoen, P.; Nordfang, O.; Reutelingsperger, C.; Hemker, H.C. Activation of factor X and its regulation by tissue factor pathway inhibitor in small-diameter capillaries lined with human endothelial cells. Blood, 1992, 79, 2909-2916.

[71] van der Logt, C.P.; Dirven, R.J.; Reitsma, P.H.; Bertina, R.M. Expression of tissue factor and tissue factor pathway inhibitor in monocytes in response to bacterial lipopolysaccharide and phorbolester. Blood Coagul. Fibrinolysis, 1994, 5, 211-220.

[72] Werling, R.W.; Zacharski, L.R.; Kisiel, W.; Bajaj, S.P.; Memoli, V.A.; Rousseau, S.M. Distribution of tissue factor pathway inhibitor in normal and malignant human tissues. Thromb. Haemost., 1993, 69, 366-369.

[73] Caplice, N.M.; Panetta, C.; Peterson, T.E.; Kleppe, L.S.; Mueske, C.S.; Kostner, G.M.; Broze, G.J.; Simari, R.D. Lipoprotein (a) binds and inactivates tissue factor pathway inhibitor: A novel link between lipoproteins and thrombosis. Blood, 2001, 98, 2980-2987.

[74] Blencowe, C.; Hermetter, A.; Kostner, G.M.; Deigner, H.P. Enhanced association of platelet-activating factor acetylhydrolase with lipoprotein (a) in comparison with low density lipoprotein. $J$. Biol. Chem., 1995, 270, 31151-31157.

[75] Tsironis, L.D.; Katsouras, C.S.; Lourida, E.S.; Mitsios, J.V.; Goudevenos, J.; Elisaf, M.; Tselepis, A.D. Reduced PAF-acetylhydrolase activity associated with $\mathrm{Lp}(\mathrm{a})$ in patients with coronary artery disease. Atherosclerosis, 2004, 177, 193-201.

[76] Tsironis, L.D.; Mitsios, J.V.; Milionis, H.J.; Elisaf, M.; Tselepis, A.D. Effect of lipoprotein (a) on platelet activation induced by platelet-activating factor: Role of apolipoprotein (a) and endogenous PAF-acetylhydrolase. Cardiovasc. Res., 2004, 63, 130138.

[77] Gries, A.; Gries, M.; Wurm, H.; Kenner, T.; Ijsseldijk, M.; Sixma, J.J.; Kostner, G.M. Lipoprotein(a) inhibits collagen-induced aggregation of thrombocytes. Arterioscler. Thromb. Vasc. Biol., 1996, 16, 648-655.

[78] Dahl, T.; Kontny, F.; Slagsvold, C.E.; Christophersen, B.; Abildgaard, U.; Odegaard, O.R.; Morkrid, L.; Dale, J. Lipoprotein(a), other lipoproteins and hemostatic profiles in patients with ischemic stroke: The relation to cardiogenic embolism. Cerebrovasc. Dis., 2000, 10, 110-117.

[79] von Depka, M.; Nowak-Göttl, U.; Eisert, R.; Dieterich, C.; Barthels, M.; Scharrer, I.; Ganser, A.; Ehrenforth, S. Increased lipoprotein (a) levels as an independent risk factor for venous thromboembolism. Blood, 2000, 96, 3364-3368.

[80] Heller, C.; Heinecke, A.; Junker, R.; Knöfler, R.; Kosch, A.; Kurnik, K.; Schobess, R.; von Eckardstein, A.; Sträter, R.; Zieger, B.; Nowak-Göttl, U.; the Childhood Stroke Study Group. Cerebral venous thrombosis in children. A multifactorial origin. Circulation, 2003, 108, 1362-1367.

[81] Nowak-Göttl, U.; Junker, R.; Hartmeier, M.; Koch, H.G.; Münchow, N.; Assmann, G.; von Eckardstein, A. Increased lipoprotein(a) is an important risk factor for venous thromboembolism in childhood. Circulation, 1999, 100, 743-748.

[82] Nowak-Göttl, U.; Sträter, R.; Heinecke, A.; Junker, R.; Koch, H.G.; Schuierer, G.; von Eckardstein, A; for the Childhood Stroke Study Group. Lipoprotein (a) and genetic polymorphisms of clotting factor $\mathrm{V}$, prothrombin, and methylenetetrahydrofolate reductase are risk factors of spontaneous ischemic stroke in childhood. Blood, 1999, 94, 3678-3682.

[83] Shindo, J.; Ishibashi, T.; Kijima, M.; Nakazato, K; Nagata, K.; Yokoyama, K.; Hirosaka, A.; Sato, E.; Kunii, H.; Yamaguchi, N.; Watanabe, N.; Saito, T.; Maehara, K.; Maruyama, Y. Increased plasminogen activator inhibitor-1 and apolipoprotein (a) in coronary atherectomy specimens in acute coronary syndromes. Coron. Artery Dis., 2001, 12, 573-579.

[84] Sträter, R.; Becker, S.; von Eckardstein, A.; Heinecke, A.; Gutsche, S.; Junker, R.; Kurnik, K.; Schobess, R.; Nowak-Göttl, U. Prospective assessment of risk factors for recurrent stroke during childhood - a 5-year follow-up study. Lancet, 2002, 360, 15401545 .

[85] Franceschini, G.; Cofrancesco, E.; Safa, O.; Boschetti, C.; Tremoli, E.; Mussoni, L.; Sirtori, C.R.; Cortellaro, M. Association of lipoprotein(a) with atherothrombotic events and fibrinolytic variables. A case-control study. Thromb. Res., 1995, 78, 227-238.

[86] Lippi, G.; Bassi, A.; Brocco, G.; Manzato, F.; Marini, M.; Guidi, G. Lipoprotein(a) concentration is not associated with venous thromboembolism in a case control study. Haematologica, 1999, 84, 726-729.

[87] März, W.; Trommlitz, M.; Scharrer, I.; Gross, W. Apolipoprotein (a) concentrations are not related to the risk of venous thrombosis. Blood Coagul. Fibrinolysis, 1991, 2, 595-599.

[88] Asanuma, Y.; Kawai, S.; Aoshima, H.; Kaburaki, I.; Mizushima, Y. Serum lipoprotein(a) and apolipoprotein(a) phenotypes in patients with rheumatoid arthritis. Arthritis Rheum., 1999, 42, 443-447.

[89] Atsumi, T.; Khamashta, M.A.; Andujar, C.; Leandro, M.J.; Amengual, O.; Ames, P.R.; Hughes, G.R. Elevated plasma lipoprotein(a) level and its association with impaired fibrinolysis in patients with antiphospholipid syndrome. J. Rheumatol., 1998, 25, 69-73.

[90] Borba, E.F.; Santos, R.D.; Bonfa, E.; Vinagre, C.G.; Pileggi, F.J.; Cossermelli, W.; Maranhao, R.C. Lipoprotein(a) levels in systemic lupus erythematosus. J. Rheumatol., 1994, 21, 220-223.

[91] Cerinic, M.M.; Valentini, G.; Sorano, G.G.; d’Angelo, S.; Cuomo, G.; Fenu, L.; Generini, S.; Cinotti, S.; Morfini, M.; Pignone, A.; Guiducci, S.; del Rossok, A.; Kalfin, R.; Das, D.; Marongiu, F. Blood coagulation, fibrinolysis, and markers of endothelial dysfunction in systemic sclerosis. Semin. Arthritis Rheum., 2003, 32, 285-295.

[92] Dieplinger, H.; Lackner, C.; Kronenberg, F.; Sandholzer, C; Lhotta, K.; Hoppichler, F.; Graf, H.; König P. Elevated plasma concentrations of lipoprotein(a) in patients with end-stage renal disease are not related to the size polymorphism of apolipoprotein(a). J. Clin. Invest., 1993, 91, 397-401.

[93] Hirata, K.; Kikuchi, S.; Saku, K.; Jimi, S.; Zhang, B.; Naito, S.; Hamaguchi, H.; Arakawa, K. Apolipoprotein(a) phenotypes and serum lipoprotein(a) levels in maintenance hemodialysis patients with/without diabetes mellitus. Kidney Int., 1993, 44, 1062-1070.

[94] Ignatescu, M.; Kostner, K.; Zorn, G.; Kneussl, M.; Maurer, G.; Lang, I.M.; Huber, K. Plasma Lp(a) levels are increased in patients with chronic thromboembolic pulmonary hypertension. Thromb. Haemost., 1998, 80, 231-232.

[95] Kronenberg, F.; Konig, P.; Neyer, U.; Auinger, M.; Pribasnig, A.; Lang, U.; Reitinger, J.; Pinter, G.; Utermann, G.; Dieplinger, H. Multicenter study of lipoprotein(a) and apolipoprotein(a) phenotypes in patients with end-stage renal disease treated by hemodialysis or continuous ambulatory peritoneal dialysis. $\mathrm{J}$. Am. Soc. Nephrol., 1995, 6, 110-120.

[96] Sechi, L.A.; Zingaro, L.; De Carli, S.; Sechi, G.; Catena, C.; Falleti, E.; Dell'Anna, E.; Bartoli, E. Increased serum lipoprotein(a) levels in patients with early renal failure. Ann. Intern. Med., 1998, 129, $457-461$.

[97] Soulat, T.; Loyau, S.; Baudouin, V.; Maisonneuve, L.; HurtaudRoux, M.F.; Schlegel, N.; Loirat, C.; Angles-Cano, E. Effect of individual plasma lipoprotein(a) variations in vivo on its competition with plasminogen for fibrin and cell binding: An in vitro study using plasma from children with idiopathic nephrotic syndrome. Arterioscler. Thromb. Vasc. Biol., 2000, 20, 575-584.

[98] Lippi, G.; Franchini, M.; Salvagno, G.L.; Guidi, G.C. Lipoprotein(a) and cancer: Anti-neoplastic effect besides its cardiovascular potency. Cancer Treat. Rev., 2007, 33, 427-436.

[99] Kim, J.S.; Chang, J.H.; Yu, H.K.; Ahn, J.H.; Yum, J.S.; Lee, S.K.; Jung, K.H.; Park, D.H.; Yoon, Y.; Byun, S.M.; Chung, S.I. Inhibition of angiogenesis and angiogenesis-dependent tumor growth by the cryptic kringle fragments of human apolipoprotein(a). J. Biol. Chem., 2003, 278, 29000-29008.

[100] Kim, J.S.; Yu, H.K.; Ahn, J.H.; Lee, H.J.; Hong, S.W.; Jung, K.H.; Chang, S.I.; Hong, Y.K.; Joe, Y.A.; Byun, S.M.; Lee, S.K.; Chung, S.I.; Yoon, Y. Human apolipoprotein(a) kringle V inhibits angiogenesis in vitro and in vivo by interfering with the activation 
of focal adhesion kinases. Biochem. Biophys. Res. Commun., 2004, 313, 534-540.

[101] Schulter, V.; Koolwijk, P.; Peters, E.; Frank, S.; Hrzenjak, A.; Graier, W.F.; van Hinsbergh, V.W.M.; Kostner, G.M. Impact of Apolipoprotein(a) on in vitro angiogenesis. Arterioscler. Thromb. Vasc. Biol., 2001, 21, 433-438.

[102] Trieu, V.N.; Uckun, F.M. Apolipoprotein(a), a link between atherosclerosis and tumor angiogenesis. Biochem. Biophys. Res. Commun., 1999, 257, 714-718.

[103] Yi, Z.F.; Cho, S.G.; Zhao; H.; Wu, Y.Y.; Luo, J.; Li, D.; Yi, T.; $\mathrm{Xu}, \mathrm{X}$;; Wu, Z.; Liu, M. A novel peptide from human apolipoprotein(a) inhibits angiogenesis and tumor growth by targeting c-Src phosphorylation in VEGF-induced human umbilical endothelial cells. Int. J. Cancer, 2009, 124, 843-852.

[104] Yu, H.K.; Kim, J.S.; Lee, H.J.; Ahn, J.H.; Lee, S.K.; Hong, S.W.; Yoon, Y. Suppression of colorectal cancer liver metastasis and extension of survival by expression of apolipoprotein(a) kringles. Cancer Res., 2004, 64, 7092-7098.

[105] Yu, H.K.; Ahn, J.H.; Lee, H.J.; Lee, S.K.; Hong, S.W.; Yoon, Y.; Kim, J.S. Expression of human apolipoprotein(a) kringles in colon cancer cells suppresses angiogenesis-dependent tumor growth and peritoneal dissemination. J. Gene Med., 2005, 7, 39-49.

[106] Lippi, G.; Guidi, G. Lipoprotein(a): From ancestral benefit to modern pathogen? Q. J. Med., 2000, 93, 75-84.

[107] Gregory, W.L.; Game, F.L.; Farrer, M.; Idle, J.R.; Laker, M.F.; James, O.F. Reduced serum lipoprotein(a) levels in patients with primary biliary cirrhosis. Atherosclerosis, 1994, 105, 43-50.

[108] Geiss, H.C.; Ritter, M.M.; Richter, W.O.; Schwandt, P.; Zachoval, R. Low lipoprotein (a) levels during acute viral hepatitis. Hepatology, 1996, 24, 1334-1337.

[109] Irshad, M. Serum lipoprotein (a) levels in liver diseases caused by hepatitis. Indian J. Med. Res., 2004, 120, 542-545.

[110] Mady, E.; Wissa, G.; Khalifa, A.; el-Sabbagh, M. Serum lipoprotein (a) levels in chronic renal failure and liver cirrhosis patients. Relationship with atherosclerosis. Dis. Markers, 1999, 15, 237-247.

[111] Jiang, J.; Nilsson-Ehle, P.; Xu, N. Influence of liver cancer on lipid and lipoprotein metabolism. Lipids Health Dis., 2006, 5, 4.

[112] Motta, M.; Giugno, I.; Ruello, P.; Pistone, G.; Di Fazio, I.; Malaguarnera, M. Lipoprotein (a) behaviour in patients with hepatocellular carcinoma. Minerva Med., 2001, 92, 301-305.

[113] Basili, S.; Andreozzi, P.; Vieri, M.; Maurelli, M.; Cara, D.; Cordova, C.; Alessandri, C. Lipoprotein (a) serum levels in patients with hepatocarcinoma. Clin. Chim. Acta, 1997, 262, 53-60.

[114] Koruk, M.; Savas, M.C.; Yilmaz, O.; Taysi, S.; Karakok, M.; Gündogdu, C.; Yilmaz, A. Serum lipids, lipoproteins and apolipoproteins levels in patients with nonalcoholic steatohepatitis. J. Clin. Gastroenterol., 2003, 37, 177-182.

[115] van der Hoek, Y.Y.; Wanders, R.J.A.; van den Ende, A.E.; Kraft, H.G.; Gabel, B.R.; Kastelein, J.J.P.; Koschinsky, M.L. Lipoprotein(a) is not present in the plasma of patients with some peroxisomal disorders. J. Lipid. Res., 1997, 38, 1612-1619.

[116] Gazzaruso, C.; Garzaniti, A.; Buscaglia, P.; D’Annunzio, G.; Porta, A.; Vandelli, G.; Lorini, R.; Finardi, G.; Fratino, P.; Geroldi, D. Lipoprotein(a) levels and apolipoprotein(a) polymorphism in type 1 diabetes mellitus: Relationships to microvascular and neurological complications. Acta Diabetol., 1998, 35, 13-18.

[117] Kapelrud, H.; Bangstad, H.J.; Dahl-Jorgensen, K.; Berg, K.; Hanssen, K.F. Serum Lp(a) lipoprotein concentrations in insulin dependent diabetic patients with microalbuminuria. BMJ, 1991, 303, 675-678.

[118] Garnotel, R.; Roussel, B.; Pennaforte, F.; Randoux, A.; Gillery, P. Changes in serum lipoprotein(a) levels in children with corticosensitive nephritic syndrome. Pediatr. Nephrol., 1996, 10, 699-701.

[119] Joven, J.; Simo, J.M.; Vilella, E.; Camps, J.; Espinel, E.; Villabona, C. Accumulation of atherogenic remnants and lipoprotein(a) in the nephrotic syndrome: Relation to remission of proteinuria. Clin. Chem., 1995, 41, 908-913.

[120] Kronenberg, F.; Lingenhel, A.; Lhotta, K.; Rantner, B.; Kronenberg, M.F.; Konig, P.; Thiery, J.; Koch, M.; von Eckardstein, A.; Dieplinger, H. The apolipoprotein(a) size polymorphism is associated with nephrotic syndrome. Kidney Int., 2004, 65, 606-612.

[121] Kronenberg, F.; Kuen, E.; Ritz, E.; Junker, R.; König, P.; Kraatz, G.; Lhotta, K.; Mann, J.F.E.; Müller, G.A.; Neyer, U.; Riegel, W.;
Riegler, P.; Schwenger, V.; von Eckardstein, A. Lipoprotein(a) serum concentrations and apolipoprotein(a) phenotypes in mild and moderate renal failure. J. Am. Soc. Nephrol., 2000, 11, 105-115.

[122] Kronenberg, F.; Neyer, U.; Lhotta, K.; Trenkwalder, E.; Auinger, M.; Pribasnig, A.; Meisl, T.; König, P.; Dieplinger, H. The low molecular weight apo(a) phenotype is an independent predictor for coronary artery disease in hemodialysis patients: A prospective follow-up. J. Am. Soc. Nephrol., 1999, 10, 1027-1036.

[123] Longenecker, J.C.; Klag, M.J.; Marcovina, S.M.; Liu, Y.M.; Jaar, B.G.; Powe, N.R.; Fink, N.E.; Levey, A.S.; Coresh, J. High lipoprotein(a) levels and small apolipoprotein(a) size prospectively predict cardiovascular events in dialysis patients. J. Am. Soc. Nephrol., 2005, 16, 1794-1802.

[124] Longenecker, J.C.; Klag, M.J.; Marcovina, S.M.; Powe, N.R.; Fink, N.E.; Giaculli, F.; Coresh, J. Small apolipoprotein(a) size predicts mortality in end-stage renal disease: the choice study. Circulation, 2002, 106, 2812-2818.

[125] Wanner, C. Clinical significance of lipoprotein(a) determination in patients with renal disease. J. Nephrol., 1996, 9, 157-159.

[126] Yun, K.A.; Lee, W.; Min, W.K.; Chun, S.; Lee, Y.W.; Kim, S.B.; Park, J.S.; Yang, W.S.; Park, H.; Hwang, S.H. Discrepancy of interleukin-6 levels between end-stage renal disease patients and patients with acute-phase response with increased lipoprotein(a) concentrations. Scand. J. Clin. Lab. Invest., 2004, 64, 223-228.

[127] Zimmermann, J.; Herrlinger, S.; Pruy, A.; Metzger, T.; Wanner, C. Inflammation enhances cardiovascular risk and mortality in hemodialysis patients. Kidney Int., 1999, 55, 648-658.

[128] Astor, B.C.; Eustace, J.A.; Klag, M.J.; Powe, N.R.; Longenecker, J.C.; Fink, N.E.; Marcovina, S.M.; Coresh, J.; for the CHOICE study. Race-specific association of lipoprotein(a) with vascular access interventions in hemodialysis patients: the choice study. Kidney Int., 2002, 61, 1115-1123.

[129] Koch, M.; Kutkuhn, B.; Trenkwalder, E.; Bach, D.; Grabensee, B.; Dieplinger, H.; Kronenberg, F. Apolipoprotein B, fibrinogen, HDL cholesterol, and apolipoprotein(a) phenotypes predict coronary artery disease in hemodialysis patients. J. Am. Soc. Nephrol., 1997, 8, 1889-1898.

[130] Longenecker, J.C.; Coresh, J.; Marcovina, S.M.; Powe, N.R.; Levey, A.S.; Giaculli, F.; Fink, N.E.; Klag, M.J. Lipoprotein(a) and prevalent cardiovascular disease in a dialysis population: The Choices for Healthy Outcomes in Caring for ESRD (CHOICE) study. Am. J. Kidney Dis., 2003, 42, 108-116.

[131] Webb, A.T.; Reaveley, D.A.; O’Donnel, M.; O’Connor, B.; Seed, M.; Brown, E.A. Lipids and lipoprotein(a) as risk factors for vascular disease in patients on renal replacement therapy. Nephrol. Dial. Transplant., 1995, 10, 354-357.

[132] Min, W.K.; Lee, J.O.; Huh, J.W. Relation between lipoprotein(a) concentrations in patients with acute-phase response and risk analysis for coronary heart disease. Clin. Chem., 1997, 43, 18911895.

[133] Dursunoglu, D.; Evrengül, H.; Polat, B.; Tanriverdi, H.; Cobankara, V.; Kaftan, A.; Kilic, M. Lp(a) lipoprotein and lipids in patients with rheumatoid arthritis: Serum levels and relationship to inflammation. Rheumatol. Int., 2005, 25, 241-245.

[134] Lippi, G.; Braga, V.; Adami, S.; Guidi, G. Modification of serum apolipoprotein A-I, apolipoprotein B and lipoprotein(a) levels after bisphosphonates-induced acute phase response. Clin. Chim. Acta, 1998, 271, 79-87.

[135] Güvener, M.; Ucar, I.; Ozkan, M.; Dogan, O.F.; Serter, F.T.; Pasaoglu, I. Effect of cardiopulmonary bypass on plasma levels of lipoprotein (a) in hypercholesterolemic patients. Jpn. Heart J., 2001, 42, 563-574.

[136] Maeda, S.; Abe, A.; Seishima, M.; Makino, K.; Noma, A.; Kawade, M. Transient changes of serum lipoprotein(a) as an acute phase protein. Atherosclerosis, 1989, 78, 145-150.

[137] Noma, A.; Abe, A.; Maeda, S.; Seishima, M.; Makino, K.; Yano, Y.; Shimokawa, K. Lp(a): An acute phase reactant? Chem. Phys. Lipids, 1994, 67-68, 411-417.

[138] Singh, R.B.; Pella, D.; Sharma, J.P.; Rastogi, S.; Kartikey, K.; Goel, V.K.; Sharma, R.; Neki, N.S.; Kumar, A.; Otsuka, K. Increased concentrations of lipoprotein(a), circadian rhythms and metabolic reactions evoked by acute myocardial infarction, associated with acute reactions in relation to large breakfasts. Biomed. Pharmacother., 2004, 58 (Suppl. 1), S116-S122. 
[139] Slunga, L.; Johnson, O.; Dahlen, G.H.; Eriksson, S. Lipoprotein(a) and acute-phase proteins in acute myocardial infarction. Scand. $J$. Clin. Lab. Invest., 1992, 52, 95-101.

[140] Byrne, D.J.; Jagroop, I.A.; Montgomery, H.E.; Thomas, M.; Mikhailidis, D.P.; Milton, N.G.; Winder, A.F. Lipoprotein (a) does not participate in the early acute phase response to training or extreme physical activity and is unlikely to enhance any associated immediate cardiovascular risk. J. Clin. Pathol., 2002, 55, 280-285.

[141] Mooser, V.; Berger, M.M.; Tappy, L.; Cayeux, C.; Marcovina, S.M.; Darioli, R.; Nicod, P.; Chiolero, R. Major reduction in plasma $\mathrm{Lp}$ (a) levels during sepsis and burns. Arterioscler. Thromb. Vasc. Biol., 2000, 20, 1137-1142.

[142] Dullaart, R.P.; van Doormaal, J.J.; Hoogenberg, K.; Sluiter, W.J. Triiodothyronine rapidly lowers plasma lipoprotein(a) in hypothyroid subjects. Neth. J. Med., 1995, 46, 179-184.

[143] Duntas, L.H. Thyroid disease and lipids. Thyroid, 2002, 12, $287-$ 293.

[144] Engler, H.; Riesen, W.F. Effect of thyroid function on concentrations of lipoprotein (a). Clin. Chem., 1993, 39, 24662469.

[145] Pearce, E.N. Hypothyroidism and dyslipidemia: Modern concepts and approaches. Curr. Cardiol. Rep., 2004, 6, 451-456.

[146] Becerra, A.; Bellido, D.; Luengo, A.; Piedrola, G.; De Luis, D.A. Lipoprotein(a) and other lipoproteins in hypothyroid patients before and after thyroid replacement therapy. Clin. Nutr., 1999, 18, 319-322.

[147] de Bruin, T.W.A.; van Barlingen, H.; van Linde-Sibenius Trip, M.; van Vuurst de Vries, A.R.R.; Akveld, M.J.; Erkelens, D.W. Lipoprotein(a) and apolipoprotein B plasma concentrations in hypothyroid, euthyroid, and hyperthyroid subjects. J. Clin. Endocrinol. Metab., 1993, 76, 121-126.

[148] Tzotzas, T.; Krassas, G.E.; Konstantinidis, T.; Bougoulia, M. Changes in lipoprotein(a) levels in overt and subclinical hypothyroidism before and during treatment. Thyroid, 2000, 10, 803-808

[149] Lee, W.Y.; Suh, J.Y.; Rhee, E.J.; Park, J.S.; Sung, K.C.; Kim, S.W. Plasma CRP, apolipoprotein A-1, apolipoprotein B and Lpa levels according to thyroid function status. Arch. Med. Res., 2004, 35, 540-545.

[150] Caraccio, N.; Ferrannini, E.; Monzani, F. Lipoprotein profile in subclinical hypothyroidism: Response to levothyroxine replacement; a randomized placebo-controlled study. J. Clin. Endocrinol. Metab., 2002, 87, 1533-1538.

[151] Kung, A.W.; Pang, R.W.; Janus, E.D. Elevated serum lipoprotein(a) in subclinical hypothyroidism. Clin. Endocrinol. (Oxf.), 1995, 43, 445-449.

[152] Milionis, H.J.; Efstathiadou, Z.; Tselepis, A.D.; Bairaktari, E.T.; Tsironis, L.D.; Tsatsoulis, A.; Elisaf, M.S. Lipoprotein (a) levels and apolipoprotein (a) isoform size in patients with subclinical hypothyroidism: Effect of treatment with levothyroxine. Thyroid, 2003, 13, 365-369.

[153] Yildirimkaya, M.; Ozata, M.; Yilmaz, K.; Kilinc, C.; Gündogan, M.A.; Kutluay, T. Lipoprotein(a) concentration in subclinical hypothyroidism before and after levo-thyroxine therapy. Endocr. J., 1996, 43, 731-736.

[154] Erem, C.; Deger, O.; Bostan, M.; Orem, A.; Sönmez, M.; Ulusoy, S.; Telatar, M. Plasma lipoprotein (a) concentrations in hypothyroid, euthyroid and hyperthyroid subjects. Acta Cardiol., 1999, 54, 77-81.

[155] Kung, A.W.; Pang, R.W.; Lauder, I.; Lam, K.S.; Janus, E.D. Changes in serum lipoprotein(a) and lipids during treatment of hyperthyroidism. Clin. Chem., 1995, 41, 226-231.

[156] Engler, H.; Riesen, W.F. Effect of thyroid hormones on $L p(a)$ and lipid metabolism. Clin. Chem. Lab. Med., 1998, 36, 731-735.

[157] Pazos, F.; Alvarez, J.J.; Rubies-Prat, J.; Varela, C.; Lasuncion, M.A. Long-term thyroid replacement therapy and levels of lipoprotein(a) and other lipoproteins. J. Clin. Endocrinol. Metab., 1995, $80,562-566$.

[158] Martinez-Triguero, M.L.; Hernandez-Mijares, A.; Nguyen, T.T.; Munoz, M.L.; Pena, H.; Morillas, C.; Lorente, D.; Lluch, I.; Molina, E. Effect of thyroid hormone replacement on lipoprotein(a), lipids, and apolipoproteins in subjects with hypothyroidism. Mayo Clin. Proc., 1998, 73, 837-841.

[159] Spandrio, S.; Sleiman, I.; Scalvini, T.; Salvi, A.; Di Stefano, O.; Pagliaini, R.; Balestrieri, G.P. Lipoprotein (a) in thyroid dysfunction before and after treatment. Horm. Metab. Res., 1993, 25, 586-589.

[160] Arem, R.; Escalante, D.A.; Arem, N.; Morrisett, J.D.; Patsch, W. Effect of L-thyroxine therapy on lipoprotein fractions in overt and subclinical hypothyroidism, with special reference to lipoprotein(a). Metabolism, 1995, 44, 1559-1563.

[161] Ito, M.; Arishima, T.; Kudo, T.; Nishihara, E.; Ohye, H.; Kubota, S.; Fukata, S.; Amino, N.; Kuma, K.; Sasaki, I.; Hiraiwa, T.; Hanafusa, T.; Takamatsu, J.; Miyauchi, A. Effect of levo-thyroxine replacement on non-high-density lipoprotein cholesterol in hypothyroid patients. J. Clin. Endocrinol. Metab., 2007, 92, 608611.

[162] Perez, A.; Cubero, J.M.; Sucunza, N.; Ortega, E.; Arcelus, R.; Rodriguez-Espinosa, J.; Ordonez-Llanos, J.; Blanco-Vaca, F. Emerging cardiovascular risk factors in subclinical hypothyroidism: Lack of change after restoration of euthyroidism. Metabolism, 2004, 53, 1512-1515.

[163] Frazer, K.A.; Narla, G.; Zhang, J.L.; Rubin, E.M. The apolipoprotein(a) gene is regulated by sex hormones and acute phase inducers in YAC transgenic mice. Nat. Genet., 1995, 9, 424431.

[164] Denti, L.; Pasolini, G.; Ablondi, F.; Valenti, G. Correlation between plasma lipoprotein $\mathrm{Lp}(\mathrm{a})$ and sex hormone concentrations: A cross-sectional study in healthy males. Horm. Metab. Res., 1994, 26, 602-608.

[165] Denti, L.; Pasolini, G.; Sanfelici, L.; Benedetti, R.; Cecchetti, A.; Ceda, G.P.; Ablondi, F.; Valenti, G. Aging-related decline of gonadal function in healthy men: Correlation with body composition and lipoproteins. J. Am. Geriatr. Soc., 2000, 48, 5158.

[166] Haffner, S.M.; Mykkanen, L.; Gruber, K.K.; Rainwater, D.L.; Laakso, M. Lack of association between sex hormones and Lp(a) concentrations in American and Finnish men. Arterioscler. Thromb., 1994, 14, 19-24.

[167] Marcovina, S.M.; Lippi, G.; Bagatell, C.J.; Bremner, W.J. Testosterone-induced suppression of lipoprotein(a) in normal men; relation to basal lipoprotein(a) level. Atherosclerosis, 1996, 122, 89-95.

[168] Marques-Vidal, P.; Sie, P.; Cambou, J.P.; Chap, H.; Perret, B Relationships of plasminogen activator inhibitor activity and lipoprotein(a) with insulin, testosterone, 17ß-estradiol, and testosterone binding globulin in myocardial infarction patients and healthy controls. J. Clin. Endocrinol. Metab., 1995, 80, 1794-1798.

[169] von Eckardstein, A.; Wu, F.C.W. Testosterone and atherosclerosis. Growth Horm. IGF Res., 2003, 13(Suppl. A), S72-S84.

[170] Weidemann, W.; Hanke H. Cardiovascular effects of androgens. Cardiovasc. Drug Rev., 2002, 20, 175-198.

[171] Wu, F.C.W.; von Eckardstein, A. Androgens and coronary artery disease. Endocr. Rev., 2003, 24, 183-217.

[172] Anderson, R.A.; Wallace, E.M.; Wu, F.C. Effect of testosterone enanthate on serum lipoproteins in man. Contraception, 1995, 52, 115-119.

[173] Berglund, L.; Carlström, K.; Stege, R.; Gottlieb, C.; Eriksson, M.; Angelin, B.; Henriksson, P. Hormonal regulation of serum lipoprotein(a) levels: Effects of parenteral administration of estrogen or testosterone in males. J. Clin. Endocrinol. Metab., 1996, 81, 2633-2637.

[174] Zmunda, J.M.; Thompson, P.D.; Dickenson, R.; Bausserman, L.L. Testosterone decreases lipoprotein(a) in men. Am. J. Cardiol., 1996, 77, 1244-1247.

[175] Flöter, A.; Nathorst-Böös, J.; Carlström, K.; von Schoultz, B. Serum lipids in oophorectomized women during estrogen and testosterone replacement therapy. Maturitas, 2004, 47, 123-129.

[176] Crook, D.; Sidhu, M.; Seed, M.; O’Donnel, M.; Stevenson, J.C. Lipoprotein $\mathrm{Lp}(\mathrm{a})$ levels are reduced by danazol, an anabolic steroid. Atherosclerosis, 1992, 92, 41-47.

[177] Hartgens, F.; Rietjens, G.; Keizer, H.A.; Kuipers, H.; Wolffenbuttel, B.H.R. Effects of androgenic-anabolic steroids on apolipoproteins and lipoprotein(a). Br. J. Sports Med., 2004, 38, 253-259.

[178] Hislop, M.S.; St. Clair Gibson, A.; Lambert, M.I.; Noakes, T.D.; Marais, A.D. Effects of androgen manipulation on postprandial triglyceridemia, low-density lipoprotein particle size and lipoprotein(a) in men. Atherosclerosis, 2001, 159, 425-432.

[179] Lippi, G.; Guidi, G.; Ruzzenente, O.; Braga, V.; Adami, S. Effects of nandrolone decanoate (Decadurabolin) on serum Lp(a), lipids 
and lipoproteins in women with postmenopausal osteoporosis. Scand. J. Clin. Lab. Invest., 1997, 57, 507-511.

[180] Teruel, J.L.; Lasuncion, M.A.; Rivera, M.; Aguilera, A.; Ortega, H.; Tato, A.; Marcen, R.; Ortuno, J. Nandrolone decanoate reduces serum lipoprotein(a) concentrations in hemodialysis patients. Am. J. Kidney Dis., 1997, 29, 569-575.

[181] Noyan, V.; Yucel, A.; Sagsoz, N. The association of androgenic sex steroids with serum lipid levels in postmenopausal women. Acta Obstet. Gynecol. Scand., 2004, 83, 487-490.

[182] Sulcova, J.; Hill, M.; Hampl, R.; Masek, Z.; Novacek, A.; Ceska, R.; Starka, L. Effects of transdermal application of DHEA on the levels of steroids, gonadotropins and lipids in men. Physiol. Res., 2000, 49, 685-693.

[183] Barnhart, K.T.; Freeman, E.; Grisso, J.A.; Rader, D.J.; Sammel, M.; Kapoor, S.; Nestler, J.E. The effect of dehydroepiandrosterone supplementation to symptomatic perimenopausal women on serum endocrine profiles, lipid parameters, and health related quality of life. J. Clin. Endocrinol. Metab., 1999, 84, 3896-3902.

[184] Arrer, E.; Jungwirth, A.; Mack, D.; Frick, J.; Patsch, W. Treatment of prostate cancer with gonadotropin-releasing hormone analogue: Effect on lipoprotein(a). J. Clin. Endocrinol. Metab., 1996, 81, 2508-2511.

[185] Denti, L.; Pasolini, G.; Cortellini, P.; Ferretti, S.; Sanfelici, L.; Ablondi, F.; Valenti, G. Effects of androgen suppression by gonadotropin-releasing hormone agonist and flutamide on lipid metabolism in men with prostate cancer: focus on lipoprotein(a). Clin. Chem., 1996, 42, 1176-1181.

[186] von Eckardstein, A.; Kliesch, S.; Nieschlag, E.; Chirazi, A.; Assmann, G.; Behre, H.M. Suppression of endogenous testosterone in young men increases serum levels of high density lipoprotein subclass lipoprotein A-I and lipoprotein(a). J. Clin. Endocrinol. Metab., 1997, 82, 3367-3372.

[187] Denti, L.; Pasolini, G.; Cortellini, P.; Sanfelici, L.; Benedetti, R.; Cecchetti, A.; Ferretti, S.; Bruschieri, L.; Ablondi, F.; Valenti, G. Changes in HDL-cholesterol and lipoprotein Lp(a) after 6-month treatment with finasteride in males affected by benign prostatic hyperplasia (BPH). Atherosclerosis, 2000, 152, 159-166.

[188] Hodgin, J.B.; Maeda, N. Minireview: estrogen and mouse models of atherosclerosis. Endocrinology, 2002, 143, 4495-4501.

[189] Moskowitz, D. A comprehensive review of the safety and efficacy of bioidentical hormones for the management of menopause and related health risks. Altern. Med. Rev., 2006, 11, 208-223.

[190] Elhadd, T.A.; Neary, R.; Abdu, T.A.; Kennedy, G.; Hill, A.; McLaren, M.; Akber, M.; Belch, J.J.; Clayton R.N. Influence of the hormonal changes during the normal menstrual cycle in healthy young women on soluble adhesion molecules, plasma homocysteine, free radical markers and lipoprotein fractions. Int. Angiol., 2003, 22, 222-228.

[191] Haines, C.J.; Cheung, L.P.; Lam, C.W. Changes in atherogenic lipids and lipoproteins during natural and hyperstimulated cycles in healthy women. Fertil. Steril., 1997, 68, 231-235.

[192] Reed, R.G.; Kris-Etherton, P.; Stewart, P.W.; Pearson, T.A. Variation of lipids and lipoproteins in premenopausal women compared with men and postmenopausal women. DELTA (Dietary Effects on Lipoproteins and Thrombogenic Activity) Investigators. Metabolism, 2000, 49, 1101-1105.

[193] Ricci, G.; Tamaro, G.; Simeone, R.; Giolo, E.; Nucera, G.; de Seta, F.; Guaschino, S. Lipoprotein(a) changes during natural menstrual cycle and ovarian stimulation with recombinant and highly purified urinary FSH. Hum. Reprod., 2001, 16, 449-456.

[194] Bruschi, F.; Meschia, M.; Soma, M.; Perotti, D.; Paoletti, R.; Crosignani, P.G. Lipoprotein(a) and other lipids after oophorectomy and estrogen replacement therapy. Obstet. Gynecol., 1996, 88, 950-954.

[195] Kim, C.J.; Ryu, W.S.; Kwak, J.W.; Park, C.T.; Ryoo, U.H. Changes in Lp(a) lipoprotein and lipid levels after cessation of female sex hormone production and estrogen replacement therapy. Arch. Intern. Med., 1996, 156, 500-504.

[196] Saarto, T.; Blomqvist, C.; Ehnholm, C.; Taskinen, M.R.; Elomaa, I. Effects of chemotherapy-induced castration on serum lipids and apoproteins in premenopausal women with node-positive breast cancer. J. Clin. Endocrinol. Metab., 1996, 81, 4453-4457.

[197] Haines, C.J.; Chung, T.K.; Masarei, J.R.; Tomlinson, B.; Lau, J.T. The effect of percutaneous oestrogen replacement therapy on $\operatorname{Lp}(\mathrm{a})$ and other lipoproteins. Maturitas, 1995, 22, 219-225.
[198] Minozzi, M.; Costabile, L.; Cosmi, E.; Donadio, F.; De Filippis, E.; Cosmi, E.V. Beneficial effects of low doses of ethinyl-estradiol on the lipid profile in postmenopausal women. Clin. Exp. Obstet. Gynecol., 2001, 28, 81-82.

[199] Suda, Y.; Ohta, H.; Makita, K.; Takamatsu, K.; Horiguchi, F.; Nozawa, S. Influence of bilateral oophorectomy upon lipid metabolism. Maturitas, 1998, 29, 147-154.

[200] Henriksson, P.; Angelin, B.; Berglund, L. Hormonal regulation of serum Lp(a) levels. Opposite effects after estrogen treatment and orchidectomy in males with prostatic carcinoma. J. Clin. Invest., 1992, 89, 1166-1171.

[201] Hiraga, T.; Shimokawa, K.; Murase, T.; Yokoyama, M. Reduction of serum lipoprotein (a) by estrogen in men with prostatic cancer. Endocr. J., 1993, 40, 507-513.

[202] von Schoultz, B.; Carlström, K.; Collste, L.; Eriksson, A.; Henriksson, P.; Pousette, A.; Stege, R. Estrogen therapy and liver function - metabolic effects of oral and parenteral administration. Prostate, 14, 1989, 389-395.

[203] Velazquez, E.M.; Mendoza, S.G.; Wang, P.; Glueck, C.J. Metformin therapy is associated with a decrease in plasma plasminogen activator inhibitor-1, lipoprotein(a), and immunoreactive insulin levels in patients with the polycystic ovary syndrome. Metabolism, 1997, 46, 454-457.

[204] Yilmaz, M.; Biri, A.; Bukan, N.; Karakoc, A.; Sancak, B.; Törüner, F.; Pasaoglu, H. Levels of lipoprotein and homocysteine in nonobese and obese patients with polycystic ovary syndrome. Gynecol. Endocrinol., 2005, 20, 258-263.

[205] Matthews, K.A.; Meilahn, E.; Kuller, L.H.; Kelsey, S.F.; Caggiula, A.W.; Wing, R.R. Menopause and risk factors for coronary heart disease. N. Engl. J. Med., 1989, 321, 641-646.

[206] Bayrak, A.; Aldemir, D.A.; Bayrak, T.; Corakci, A.; Dursun, P. The effect of hormone replacement therapy on the levels of serum lipids, apolipoprotein AI, apolipoprotein B and lipoprotein (a) in Turkish postmenopausal women. Arch. Gynecol. Obstet., 2006, 274, 289-296.

[207] Shlipak, M.G.; Simon, J.A.; Vittinghoff, E.; Lin, F.; BarrettConnor, E.; Knopp, R.H.; Levy, R.I.; Hulley, S.B. Estrogen and progestin, lipoprotein(a), and the risk of recurrent coronary heart disease events after menopause. JAMA, 2000, 283, 1845-1852.

[208] Ushioda, M.; Makita, K.; Takamatsu, K.; Horiguchi, F.; Aoki, D. Serum lipoprotein(a) dynamics before/after menopause and longterm effects of hormone replacement therapy on lipoprotein(a) levels in middle-aged and older Japanese women. Horm. Metab. Res., 2006, 38, 581-586.

[209] Darling, G.M.; Johns, J.A.; McCloud, P.I.; Davis, S.R. Estrogen and progestin compared with simvastatin for hypercholesterolemia in postmenopausal women. N. Engl. J. Med., 1997, 337, 595-601.

[210] Espeland, M.A.; Marcovina, S.M.; Miller, V.; Wood, P.D.; Wasilauskas, C.; Sherwin, R.; Schrott, H.; Bush, T.L.; for the Pepi Investigators. Effect of postmenopausal hormone therapy on lipoprotein(a) concentration. Circulation, 1998, 97, 979-986.

[211] Falco, C.; Tormo, G.; Estelles, A.; Espana, F.; Tormo, E.; Gilabert, J.; Velasco, J.A.; Aznar, J. Fibrinolysis and lipoprotein(a) in women with coronary artery disease. Influence of hormone replacement therapy. Haematologica, 2001, 86, 92-98.

[212] Hemelaar, M.; van der Mooren, M.J.; Mijatovic, V.; Bouman, A.A.; Schijf, C.P.; Kroeks, M.V.; Franke, H.R.; Kenemans, P. Oral, more than transdermal, estrogen therapy improves lipids and lipoprotein(a) in postmenopausal women: a randomized, placebocontrolled study. Menopause, 2003, 10, 550-558.

[213] Ko, H.S.; Kim, C.J.; Ryu, W.S. Overweight and effect of hormone replacement therapy on lipid profiles in postmenopausal women. Korean J. Intern. Med., 2005, 20, 33-39.

[214] Nabulsi, A.A.; Folsom, A.R.; White, A.; Patsch, W.; Heiss, G.; Wu, K.K.; Szklo, M. Association of hormone-replacement therapy with various cardiovascular risk factors in postmenopausal women. The Atherosclerosis Risk in Communities Study Investigators. $N$. Engl. J. Med., 1993, 328, 1069-1075.

[215] Sbarouni, E.; Flevari, P.; Kroupis, C.; Kyriakides, Z.S.; Koniavitou, K.; Kremastinos, D.T. The effects of raloxifene and simvastatin on plasma lipids and endothelium. Cardiovasc. Drugs Ther., 2003, 17, 319-323.

[216] Seed, M.; Sands, R.H.; McLaren, M.; Kirk, G.; Darko, D. The effect of hormone replacement therapy and route of administration on selected cardiovascular risk factors in post-menopausal women. Fam. Pract., 2000, 17, 497-507. 
[217] Shewmon, D.A.; Stock, J.L.; Rosen, C.J.; Heiniluoma, K.M.; Hogue, M.M.; Morrison, A.; Doyle, E.M.; Ukena, T.; Weale, V.; Baker, S. Tamoxifen and estrogen lower circulating lipoprotein(a) concentrations in healthy postmenopausal women. Arterioscler. Thromb., 1994, 14, 1586-1593.

[218] Soma, M.R.; Meschia, M.; Bruschi, F.; Morrisett, J.D.; Paoletti, R.; Fumagalli, R.; Crosignani, P. Hormonal agents used in lowering lipoprotein(a). Chem. Phys. Lipids, 1994, 67-68, 345-350.

[219] Soma, M.R.; Osnago-Gadda, I.; Paoletti, R.; Fumagalli, R.; Morrisett, J.D.; Meschia, M.; Crosignani, P. The lowering of lipoprotein(a) induced by estrogen plus progesterone replacement therapy in postmenopausal women. Arch. Intern. Med., 1993, 153, 1462-1468.

[220] Decensi, A.; Robertson, C.; Ballardini, B.; Paggi, D.; GuerrieriGonzaga, A.; Bonanni, B.; Manetti, L.; Johansson, H.; Barreca, A.; Bettega, D.; Costa, A. Effect of tamoxifen on lipoprotein(a) and insulin-like growth factor-I (IGF-I) in healthy women. Eur. J. Cancer, 1999, 35, 596-600.

[221] Kusama, M.; Miyauchi, K.; Aoyama, H.; Sano, M.; Kimura, M.; Mitsuyama, S.; Komaki, K.; Doihara, H. Effects of toremifene (TOR) and tamoxifen (TAM) on serum lipids in postmenopausal patients with breast cancer. Breast Cancer Res. Treat., 2004, 88, 18 .

[222] Liberopoulos, E.; Karabina, S.A.; Tselepis, A.; Bairaktari, E.; Nicolaides, C.; Pavlidis, N.; Elisaf, M. Are the effects of tamoxifen on the serum lipid profile modified by apolipoprotein $\mathrm{E}$ phenotypes? Oncology, 2002, 62, 115-120.

[223] Sharma, D.; Sharma, U.; Bhatnagar, V.B.; Singh, V.S. A comparative of the effect of tamoxifen on serum lipid and lipoprotein profile in premenopausal \& postmenopausal women with breast carcinoma \& associated risk of vascular complication. Indian J. Med. Sci., 2001, 55, 37-42.

[224] Shewmon, D.A.; Stock, J.L.; Abusamra, L.C.; Kristan, M.A.; Baker, S.; Heiniluoma, K.M. Tamoxifen decreases lipoprotein (a) in patients with breast cancer. Metabolism, 1994, 43, 531-532.

[225] Vrbanec, D.; Reiner, Z.; Belev, B.; Plestina, S. Changes in serum lipid and lipoprotein levels in postmenopausal patients with nodepositive breast cancer treated with tamoxifen. Tumori, 1998, 84, 687-690.

[226] Wasan, K.M.; Goss, P.E.; Pritchard, P.H.; Shepherd, L.; Palmer, M.J.; Liu, S.; Tu, D.; Ingle, J.N.; Heath, M.; Deangelis, D.; Perez, E.A. The influence of letrozole on serum lipid concentrations in postmenopausal women with primary breast cancer who have completed 5 years of adjuvant tamoxifen (NCIC CTG MA.17L). Ann. Oncol., 2005, 16, 707-715.

[227] Arnadottir, M.; Berg, A.L.; Dallongeville, J.; Fruchart, J.C.; Nilsson-Ehle, P. Adrenocorticotrophic hormone lowers serum Lp(a) and LDL cholesterol concentrations in hemodialysis patients. Kidney Int., 1997, 52, 1651-1655.

[228] Arnadottir, M.; Berg, A.L.; Kronenberg, F.; Lingenhel, A.; Hugosson, T.; Hegbrant, J.; Nilsson-Ehle, P. Corticotropin-induced reduction of plasma lipoprotein(a) concentrations in healthy individuals and hemodialysis patients: Relation to apolipoprotein(a) size polymorphism. Metabolism, 1999, 48, 342-346.

[229] Berg, A.L.; Rafnsson, A.T.; Johannsson, M.; Dallongeville, J.; Arnadottir, M. The effects of adrenocorticotrophic hormone and an equivalent dose of cortisol on the serum concentrations of lipids, lipoproteins, and apolipoproteins. Metabolism, 2006, 55, 10831087.

[230] Clodi, M.; Oberbauer, R.; Waldhäusl, W.; Maurer, G.; Kostner, G.M.; Kostner, K. Urinary excretion of apo(a) fragments in NIDDM patients. Diabetologia, 1997, 40, 1455-1460.

[231] Laron, Z.; Wang, X.L.; Klinger, B.; Silbergeld, A.; Wilcken, D.E. Growth hormone increases and insulin-like growth factor-I decreases circulating lipoprotein(a). Eur. J. Endocrinol., 1997, 136, 377-381.

[232] Eden, S.; Wiklund, O.; Oscarsson, J.; Rosen, T.; Bengtsson, B.A. Growth hormone treatment of growth hormone-deficient adults results in a marked increase in $\mathrm{Lp}(\mathrm{a})$ and HDL cholesterol concentrations. Arterioscler. Thromb., 1993, 13, 296-301.

[233] Hershkovitz, E.; Belotserkovsky, O.; Limony, Y.; Leiberman, E.; Shany, S.; Phillip, M. Increase of serum lipoprotein (a) levels during growth hormone therapy in normal short children. Eur. J. Pediatr., 1998, 157, 4-7.

[234] Nolte, W.; Rädisch, C.; Armstrong, V.W.; Hüfner, M.; von zur Mühlen, A. The effect of recombinant human GH replacement therapy on lipoprotein(a) and other lipid parameters in adults with acquired GH deficiency: Results of a double-blind and placebocontrolled trial. Eur. J. Endocrinol., 1997, 137, 459-466.

[235] O’Halloran, D.J.; Wieringa, G.; Tsatsoulis, A.; Shalet, S.M. Increased serum lipoprotein(a) concentrations after growth hormone $(\mathrm{GH})$ treatment in patients with isolated $\mathrm{GH}$ deficiency. Ann. Clin. Biochem., 1996, 33, 330-334.

[236] Laron, Z.; Wang, X.L.; Klinger, B.; Silbergeld, A.; Wilcken, D.E. Insulin-like growth factor-I decreases serum lipoprotein (a) during long-term treatment of patients with Laron syndrome. Metabolism, 1996, 45, 1263-1266.

[237] Wang, X.L.; Wang, J.; Rainwater, D.L. Acute effects of insulinlike growth factor-1 and recombinant growth hormone on lipoorotein(a) levels in baboons. Metabolism, 2002, 51, 508-513.

[238] Parkinson, C.; Drake, W.M.; Wieringa, G.; Yates, A.P.; Besser, G.M.; Trainer, P.J. Serum lipoprotein changes following IGF-I normalization using a growth hormone receptor antagonist in acromegaly. Clin. Endocrinol. (Oxf.), 2002, 56, 303-311.

[239] Catena, C.; Novello, M.; Dotto, L.; De Marchi, S.; Sechi, L.A. Serum lipoprotein(a) concentrations and alcohol consumption in hypertension: Possible relevance for cardiovascular damage. $J$. Hypertens., 2003, 21, 281-288.

[240] Fontana, P.; Mooser, V.; Bovet, P.; Shamlaye, C.; Burnand, B.; Lenain, V.; Marcovina, S.M.; Riesen, W.; Darioli, R. Dosedependent inverse relationship between alcohol consumption and serum Lp(a) levels in black African males. Arterioscler. Thromb. Vasc. Biol., 1999, 19, 1075-1082.

[241] Marth, E.; Cazzolato, G.; Bittolo Bon, G.; Avogaro, P.; Kostner, G.M. Serum concentrations of lipoprotein(a) and other lipoprotein parameters in heavy alcohol consumers. Ann. Nutr. Metab., 1982, 26, 56-62.

[242] Delarue, J.; Husson, M.; Schellenberg, F.; Tichet, J.; Vol, S.; Couet, C.; Lamisse, F. Serum lipoprotein(a) (Lp(a)) in alcoholic men: effect of withdrawal. Alcohol, 1996, 13, 309-314.

[243] Huang, C.M.; Elin, R.J.; Ruddel, M.; Schmitz, J.; Linnoila, M. The effect of alcohol withdrawal on serum concentrations of Lp(a), apolipoproteins A-1 and B, and lipids. Alcohol Clin. Exp. Res., 1992, 16, 895-898.

[244] Kervinen, K.; Savolainen, M.J.; Kesäniemi, Y.A. A rapid increase in lipoprotein (a) levels after ethanol withdrawal in alcoholic men. Life Sci., 1991, 48, 2183-2188.

[245] Kervinen, K.; Savolainen, M.J.; Kesäniemi, Y.A. Lp(a) levels increase after ethanol withdrawal. Alcohol Clin. Exp. Res., 1993, $17,926$.

[246] Lecomte, E.; Herbeth, B.; Paille, F.; Steinmetz, J.; Artur, Y.; Siest, G. Changes in serum apolipoprotein and lipoprotein profile induced by chronic alcohol consumption and withdrawal: Determinant effect on heart disease? Clin. Chem., 1996, 42, 1666-1675.

[247] Paassilta, M.; Kervinen, K.; Linnaluoto, M.; Kesäniemi, Y.A. Alcohol withdrawal-induced change in lipoprotein(a): Association with the growth hormone/insulin-like growth factor-I (IGF-I)/IGFbinding protein-1 (IGFBP-1) axis. Arterioscler. Thromb. Vasc. Biol., 1998, 18, 650-654.

[248] Rakic, V.; Puddey, I.B.; Dimmitt, S.B.; Burke, V.; Beilin, L.J. A controlled trial of the effects of pattern of alcohol intake on serum lipid levels in regular drinkers. Atherosclerosis, 1998, 137, 243 252.

[249] Välimäki, M.; Kahri J.; Laitinen, K.; Lahdenperä, S.; Kuusi, T.; Ehnholm, C.; Jauhiainen, M.; Bard, J.M.; Fruchart, J.C.; Taskinen, M.R. High density lipoprotein subfractions, apolipoprotein A-I containing lipoproteins, lipoprotein (a), and cholesterol ester transfer protein activity in alcoholic women before and after ethanol withdrawal. Eur. J. Clin. Invest., 1993, 23, 406-417.

[250] Mackinnon, L.T.; Hubinger, L.; Lepre, F. Effects of physical activity and diet on lipoprotein(a). Med. Sci. Sports Exerc., 1997, 29, 1429-1436.

[251] Katan, M.B.; Zock, P.L.; Mensink, R.P. Trans fatty acids and their effects on lipoproteins in humans. Annu. Rev. Nutr., 1995, 15, 473 493.

[252] Mensink, R.P.; Katan, M.B. Trans monounsaturated fatty acids in nutrition and their impact on serum lipoprotein levels in man. Prog. Lipid. Res., 1993, 32, 111-122.

[253] Mensink, R.P.; Zock, P.L.; Katan, M.B.; Hornstra, G. Effect of dietary cis and trans fatty acids on serum lipoprotein(a) levels in humans. J. Lipid. Res., 1992, 33, 1493-1501. 
[254] Nestel, P.; Noakes, M.; Belling, B.; McArthur, R.; Clifton, P.; Janus, E.; Abbey, M. Plasma lipoprotein lipid and Lp(a) changes with substitution of elaidic acid for oleic acid in the diet. J. Lipid Res., 1992, 33, 1029-1036.

[255] Sundram, K.; Ismail, A.; Hayes, K.C.; Jeyamalar, R.; Pathmanathan, R. Trans (elaidic) fatty acids adversely affect the lipoprotein profile relative to specific saturated fatty acids in humans. J. Nutr., 1997, 127, 514S-520S.

[256] Brousseau, M.E.; Ordovas, J.M.; Nicolosi, R.J.; Schaefer, E.J. Effects of dietary fat saturation on plasma lipoprotein(a) and hepatic apolipoprotein(a) mRNA concentrations in cynomolgus monkeys. Atherosclerosis, 1994, 106, 109-118.

[257] Eritsland, J.; Arnesen, H.; Berg, K.; Seljeflot, I.; Abdelnoor, M. Serum Lp(a) lipoprotein levels in patients with coronary artery disease and the influence of long-term n-3 fatty acid supplementation. Scand. J. Clin. Lab. Invest., 1995, 55, 295-300.

[258] Marcovina, S.M.; Kennedy, H.; Bittolo Bon, G.; Cazzolato, G.; Galli, C.; Casiglia, E.; Puato, M.; Pauletto, P. Fish intake, independent of apo(a) size, accounts for lower plasma lipoprotein(a) levels in Bantu fishermen of Tanzania: the Lugalawa Study. Arterioscler. Thromb. Vasc. Biol., 1999, 19, 1250-1256.

[259] Seidel, C.; Deufel, T.; Jahreis, G. Effects of fat-modified dairy products on blood lipids in humans in comparison with other fats. Ann. Nutr. Metab., 2005, 49, 42-48.

[260] Shinozaki, K.; Kambayashi, J.; Kawasaki, T.; Uemura, Y.; Sakon, M.; Shiba, E.; Shibuya, T.; Nakamura, T.; Mori, T. The long-term effect of eicosapentaenoic acid on serum levels of lipoprotein (a) and lipids in patients with vascular disease. J. Atheroscler. Thromb., 1996, 2, 107-109.

[261] Craig, W.Y.; Palomaki, G.E.; Haddow, J.E. Cigarette smoking and serum lipid and lipoprotein concentrations: an analysis of published data. BMJ, 1989, 298, 784-788.

[262] Os, I.; Hoieggen, A.; Larsen, A.; Sandset, P.M.; Djurovic, S.; Berg, K.; Os, A.; Birkeland, K.; Westheim, A. Smoking and relation to other risk factors in postmenopausal women with coronary artery disease, with particular reference to whole blood viscosity and beta-cell function. J. Intern. Med., 2003, 253, 232-239.

[263] Rodrioguez Reguero, J.J.; Iglesias Cubero, G.; Martinez Celada, M.; Fueyo, J.R.; Sanchez Posada, I.; Braga, S.; Cortina, A. Interrelationships between lipoprotein(a) and other cardiovascular risk factors. Cardiology, 1995, 86, 432-435.

[264] Siekmeier, R.; März, W.; Kronenberger, H.; Seiffert, U.B.; Groß, W. Effects of cigarette smoking on plasma lipids, apolipoproteins, and lipoprotein (a). Clin. Chem., 1994, 40, 1350-1351.

[265] Wersch, J.W.; van Mackelenbergh, B.A.; Ubachs, J.M. Lipoprotein(a) in smoking and non-smoking pregnant women. Scand. J. Clin. Lab. Invest., 1994, 54, 361-364.

[266] Ashavaid, T.F.; Kondkar, A.A.; Todur, S.P.; Dherai, A.J.; Morey, J.; Raghavan, R. Lipid, lipoprotein, apolipoprotein and lipoprotein(a) levels: Reference intervals in a healthy Indian population. J. Atheroscler. Thromb., 2005, 12, 251-259.

[267] Selby, J.V.; Austin, M.A.; Sandholzer, C.; Quesenberry, C.P.; Zhang, D.; Mayer, E.; Utermann, G. Environmental and behavioral influences on plasma lipoprotein(a) concentration in women twins. Prev. Med., 1994, 23, 345-353.

[268] Tello-Montoliu, A.; Roldan, V.; Climent, V.E.; Sogorb, F.; Lip, G.Y.H.; Marín, F. Does smoking status influence the effect of physical exercise on fibrinolytic function in healthy volunteers? $J$. Thromb. Thrombolysis, 2006, 21, 163-166.

[269] Buyukyazi, G. Differences in blood lipids and apolipoproteins between master athletes, recreational athletes and sedentary men. $J$. Sports Med. Phys. Fitness, 2005, 45, 112-120.

[270] Hubinger, L.; Mackinnon, L.T. The effect of endurance training on lipoprotein(a) (Lp(a)) levels in middle-aged males. Med. Sci. Sports Exerc., 1996, 28, 757-764.

[271] Hubinger, L.; Mackinnon, L.T.; Barber, L.; McCosker, J.; Howard, A.; Lepre, F. Acute effects of treadmill running on lipoprotein(a) levels in males and females. Med. Sci. Sports Exerc., 1997, 29, 436-442.

[272] Hubinger, L.; Mackinnon, L.T.; Lepre, F. Lipoprotein(a) (Lp(a)) levels in middle-aged male runners and sedentary controls. Med. Sci. Sports Exerc., 1995, 27, 490-496.

[273] Kishali, N.F.; Imamoglu, O.; Kaldirimci, M.; Akyol, P.; Yildirim, $\mathrm{K}$. Comparison of lipid and lipoprotein values in men and women differing in training status. Int. J. Neurosci., 2005, 115, 1247-1257.
[274] Cardoso, G.C.; Posadas, C.; Orvananos, O.O.; Peniche, C.; Zamora, J.; Aguilar, R.; Holguin, J.A.; Raynaud, A.S.; Morrisett, J.D.; Guevara, J. Long distance runners and body-builders exhibit elevated plasma levels of lipoprotein(a). Chem. Phys. Lipids, 1994, 67-68, 207-221.

[275] Holme, I.; Urdal, P.; Anderssen, S.; Hjermann, I. Exercise-induced increase in lipoprotein (a). Atherosclerosis, 1996, 122, 97-104.

[276] Mackinnon, L.T.; Hubinger, L.M. Effects of exercise on lipoprotein(a). Sports Med., 1999, 28, 11-24.

[277] Batiste, M.C.; Schaefer, E.J. Diagnosis and management of lipoprotein abnormalities. Nutr. Clin. Care, 2002, 5, 115-123.

[278] Bays, H.; Stein, E.A. Pharmacotherapy for dyslipidaemia - current therapies and future agents. Expert. Opin. Pharmacother., 2003, 4, 1901-1938.

[279] Birjmohun, R.S.; Hutten, B.A.; Kastelein, J.J.P.; Stroes, E.S.G. Increasing HDL cholesterol with extended-release nicotinic acid: from promise to practice. Neth. J. Med., 2004, 62, 229-234.

[280] Capuzzi, D.M.; Guyton, J.R.; Morgan, J.M.; Goldberg, A.C.; Kreisberg, R.A.; Brusco, O.A.; Brody J. Efficacy and safety of an extended-release niacin (Niaspan): A long-term study. Am. J. Cardiol., 1998, 82(12A), 74U-81U.

[281] Carlson, L.A.; Hamsten, A.; Asplund, A. Pronounced lowering of serum levels of lipoprotein $\mathrm{Lp}(\mathrm{a})$ in hyperlipidaemic subjects treated with nicotinic acid. J. Intern. Med., 1989, 226, 271-276.

[282] Davidson, M.H. Niacin: a powerful adjunct to other lipid-lowering drugs in reducing plaque progression and acute coronary events. Curr. Atheroscler. Rep., 2003, 5, 418-422.

[283] Guyton, J.R.; Capuzzi, D.M. Treatment of hyperlipidemia with combined niacin-statin regimens. Am. J. Cardiol., 1998, 82(12A), 82U-84U.

[284] McCormack, P.L.; Keating, G.M. Prolonged-release nicotinic acid. A review of its use in the treatment of dyslipidemia. Drugs, 2005, $65,2719-2740$.

[285] McKenney, J. New perspectives on the use of niacin in the treatment of lipid disorders. Arch. Intern. Med., 2004, 164, 697705.

[286] Pan, J.; Van, J.T.; Chan, E.; Kesala, R.L.; Lin, M.; Charles, M.A. Extended-release niacin treatment of the atherogenic lipid profile and lipoprotein(a) in diabetes. Metabolism, 2002, 51, 1120-1127.

[287] Sprecher, D.L. Raising high-density lipoprotein cholesterol with niacin and fibrates: A comparative review. Am. J. Cardiol., 2000, 86(12A), 46L-50L.

[288] Ramharack, R.; Spahr, M.A.; Hicks, G.W.; Kieft, K.A.; Brammer, D.W.; Minton, L.L.; Newton, R.S. Gemfibrozil significantly lowers cynomolgus monkey plasma lipoprotein(a)-protein and liver apolipoprotein(a) mRNA levels. J. Lipid Res., 1995, 36, 12941304.

[289] Branchi, A.; Rovellini, A.; Fiorenza, A.M.; Sommariva, D. Effects of bezafibrate and of 2 HMG-CoA reductase inhibitors on lipoprotein (a) level in hypercholesterolemic patients. Int. J. Clin. Pharmacol. Ther., 1995, 33, 345-350.

[290] Gavish, D.; Leibovitz, E.; Shapira, I.; Rubinstein, A. Bezafibrate and simvastatin combination therapy for diabetic dyslipidaemia: Efficacy and safety. J. Intern. Med., 2000, 247, 563-569.

[291] Goa, K.L.; Barradell, L.B.; Plosker, G.L. Bezafibrate. An update of its pharmacology and use in the management of dyslipidaemia. Drugs, 1996, 52, 725-753.

[292] Jones, P.H.; Pownall, H.J.; Patsch, W.; Herd, J.A.; Farmer, J.A.; Payton-Ross, C.; Kimball, K.T.; Gotto, A.M.; Morrisett, J.D. Effect of gemfibrozil on levels of lipoprotein(a) in type II hyperlipoproteinemic subjects. J. Lipid Res., 1996, 37, 1298-1308.

[293] Sposito, A.C.; Mansur, A.P.; Maranhao, R.C.; Rodrigues-Sobrinho, C.R.M.; Coelho, O.R.; Ramires, J.A.F. Etofibrate but not controlled-release niacin decreases LDL cholesterol and lipoprotein (a) in type IIb dyslipidemic subjects. Braz. J. Med. Biol. Res., 2001, 34, 177-182.

[294] Armstrong, V.W.; Schuff-Werner, P.; Eisenhauer, T.; Helmhold, M.; Stix, M.; Seidel, D. Heparin extracorporeal LDL precipitation (HELP): An effective apheresis procedure for lowering Lp(a) levels. Chem. Phys. Lipids, 1994, 67-68, 315-321.

[295] Bambauer, R. Is lipoprotein (a)-apheresis useful? Ther. Apher. Dial., 2005, 9, 142-147.

[296] Bambauer, R.; Schneidewind, J.M.; Latza, R. Apheresis technologies for prevention and regression of atherosclerosis: Clinical results. ASAIO J., 1999, 45, 403-407. 
[297] Banyai, S.; Streicher, J.; Strobl, W.; Gabriel, H.; Gottsauner-Wolf, M.; Rohac, M.; Weidinger, F.; Hörl, W.H.; Derfler, K. Therapeutic efficiency of lipoprotein(a) reduction by low-density lipoprotein immunoapheresis. Metabolism, 1998, 47, 1058-1064.

[298] Blessing, F.; Wang, Y.; Nagel, D.; Seidel, D. The efficacy and safety of the new heparin-induced extracorporeal low-density lipoprotein precipitation system (Plasmat Futura) in comparison with the currently used system (Plasmat Secura). Ther. Apher. Dial., 2004, 8, 33-38.

[299] Bosch, T.; Gahr, S.; Belschner, U.; Schaefer, C.; Lennertz, A.; Rammo, J.; for the DALI Study Group. Direct adsorption of lowdensity lipoprotein by DALI-LDL-apheresis: Results of a prospective long-term multicenter follow-up covering 12,291 sessions. Ther. Apher. Dial., 2006, 10, 210-218.

[300] Jansen, M.; Banyai, S.; Schmaldienst, S.; Goldammer, A.; Rohac, M.; Horl, W.H.; Derfler, K. Direct adsorption of lipoproteins (DALI) from whole blood: First long-term clinical experience with a new LDL-apheresis system for the treatment of familial hypercholesterolaemia. Wien. Klin. Wochenschr., 2000, 112, 61-69.

[301] Julius, U.; Metzler, W.; Pietzsch, J.; Fassbender, T.; Klingel, R. Intraindividual comparison of two extracorporeal LDL apheresis methods: Lipidfiltration and HELP. Int. J. Artif. Organs, 2002, 25, 1180-1188.

[302] Otto, C.; Geiss, H.C.; Laubach, E.; Schwandt, P. Effects of direct adsorption of lipoproteins apheresis on lipoproteins, low-density lipoprotein subtypes, and hemorheology in hypercholesterolemic patients with coronary artery disease. Ther. Apher., 2002, 6, 130135.

[303] Otto, C.; Kern, P.; Bambauer, R.; Kallert, S.; Schwandt, P.; Parhofer, K.G. Efficacy and safety of a new whole-blood lowdensity lipoprotein apheresis system (Liposorber D) in severe hypercholesterolemia. Artif. Organs, 2003, 27, 1116-1122.

[304] Park, J.W.; Merz, M.; Braun, P. Effect of HELP-LDL-apheresis on outcomes in patients with advanced coronary atherosclerosis and severe hypercholesterolemia. Atherosclerosis, 1998, 139, 401-409.

[305] Richter, W.O.; Donner, M.G.; Schwandt, P. Three low density lipoprotein apheresis techniques in treatment of patients with familial hypercholesterolemia: a long-term evaluation. Ther. Apher., 1999, 3, 203-208.

[306] Schaumann, D.; Welch-Wichary, M.; Voss, A.; Schmidt, H.; Olbricht, C.J. Prospective cross-over comparisons of three lowdensity lipoprotein (LDL)-apheresis methods in patients with familial hypercholesterolaemia. Eur. J. Clin. Invest., 1996, 26, 1033-1038.

[307] Schmaldienst, S.; Banyai, S.; Stulnig, T.M.; Heinz, G.; Jansen, M.; Hörl, W.H.; Derfler, K. Prospective randomised cross-over comparison of three LDL-apheresis systems in statin pretreated patients with familial hypercholesterolaemia. Atherosclerosis, 2000, 151, 493-499.

[308] Schuff-Werner, P.; Gohlke, H.; Bartmann, U.; Baggio, G.; Corti, M.C.; Dinsenbacher, A.; Eisenhauer, T.; Grützmacher, P.; Keller, C.; Kettner, U. The HELP-LDL-apheresis multicentre study, an angiographically assessed trial on the role of LDL-apheresis in the secondary prevention of coronary heart disease. II. Final evaluation of the effect of regular treatment on LDL-cholesterol plasma concentrations and the course of coronary heart disease. Eur. J. Clin. Invest., 1994, 24, 724-732.

[309] Susca, M. Heparin-induced extracorporeal low-density lipoprotein precipitation Futura, a new modification of HELP apheresis: Technique and first clinical results. Ther. Apher., 2001, 5, 387-393.

[310] Tasaki, H.; Yamashita, K.; Saito, Y.; Bujo, H.; Daida, H.; Mabuchi, H.; Tominaga, Y.; Matsuzaki, M.; Fukunari, K.; Nakazawa, R.; Tsuji, M.; Kawade, Y.; Yamamoto, S.; Ueda, Y.; Takayama, K. Low-density lipoprotein apheresis therapy with a direct hemoperfusion column: A Japanese multicenter clinical trial. Ther. Apher. Dial., 2006, 10, 32-41.

[311] Castro, R.; Queiros, J.; Fonseca, I.; Pimentel, J.P.S.; Henriques, A.C.; Sarmento, A.M.; Guimaraes, S.; Pereira, M.C. Therapy of post-renal transplantation hyperlipidaemia: Comparative study with simvastatin and fish oil. Nephrol. Dial. Transplant., 1997, 12, 2140-2143.

[312] Dobs, A.S.; Prasad, M.; Goldberg, A.; Guccione, M.; Hoover, D.R. Changes in serum lipoprotein(a) in hyperlipidemic subjects undergoing long-term treatment with lipid-lowering drugs. Cardiovasc. Drugs Ther., 1995, 9, 677-684.
[313] Klausen, I.C.; Gerdes, L.U.; Meinertz, H.; Hansen, F.A.; Faergeman, O. Apolipoprotein(a) polymorphism predicts the increase of $\mathrm{Lp}(\mathrm{a})$ by pravastatin in patients with familial hypercholesterolaemia treated with bile acid sequestration. Eur. J. Clin. Invest., 1993, 23, 240-245.

[314] Ozaki, K.; Kubo, T.; Imaki, R.; Shinagawa, H.; Fukaya, H.; Ohtaki, K.; Ozaki, S.; Izumi, T.; Aizawa, Y. The anti-atherosclerotic effects of lipid lowering with atorvastatin in patients with hypercholesterolemia. J. Atheroscler. Thromb., 2006, 13, 216-219.

[315] Romero, R.; Calvino, J.; Rodriguez, J.; Sanchez-Guisande, D. Short-term effect of atorvastatin in hypercholesterolaemic renaltransplant patients unresponsive to other statins. Nephrol. Dial. Transplant., 2000, 15, 1446-1449.

[316] Samuelsson, O.; Attman, P.O.; Knight-Gibson, C.; Mulec, H.; Weiss, L.; Alaupovic, P. Fluvastatin improves lipid abnormalities in patients with moderate to advanced chronic renal insufficiency. Am. J. Kidney Dis., 2002, 39, 67-75.

[317] Solfrizzi, V.; Capurso, C.; Colacicco, A.M.; d'Introno, A.; Fontana, C.; Capurso, S.A.; Torres, F.; Gadaleta, A.M.; Koverech, A.; Capurso, A.; Panza, F. Efficacy and tolerability of combined treatment with L-carnitine and simvastatin in lowering lipoprotein(a) serum levels in patients with type 2 diabetes mellitus. Atherosclerosis, 2006, 188, 455-461.

[318] Tsimikas, S.; Witztum, J.L.; Miller, E.R.; Sasiela, W.J.; Szarek, M.; Olsson, A.G.; Schwartz, G.G.; and for the Myocardial Ischemia Reduction with Aggressive Cholesterol Lowering Study Investigators. High-dose atorvastatin reduces total plasma levels of oxidized phospholipids and immune complexes present on apolipoprotein B-100 in patients with acute coronary syndromes in the MIRACL trial. Circulation, 2004, 110, 1406-1412.

[319] Winkler, K.; Abletshauser, C.; Friedrich, I.; Hoffmann, M.M.; Wieland, H.; März, W. Fluvastatin slow-release lowers plateletactivating factor acetyl hydrolase activity: A placebo-controlled trial in patients with type 2 diabetes. J. Clin. Endocrinol. Metab., 2004, 89, 1153-1159.

[320] Leren, T.P.; Hjermann, I.; Foss, O.P.; Leren, P.; Berg, K. Longterm effect of lovastatin alone and in combination with cholestyramine on lipoprotein (a) level in familial hypercholesterolemic subjects. Clin. Investig. 1992, 70, 711-718.

[321] Wu, S.C.; Shiang, J.C.; Lin, S.L.; Wu, T.L.; Huang, W.C.; Chiou, K.R.; Liu, C.P. Efficacy and safety of statins in hypercholesterolemia with emphasis on lipoproteins. Heart Vessels, 2005, 20, 217-223.

[322] Derosa, G.; Cicero, A.F.; d’Angelo, A.; Gaddi, A.; Ciccarelli, L.; Piccinni, M.N.; Salvadeo, S.A.; Pricolo, F.; Ferrari, I.; Gravina, A.; Ragonesi, P.D. Effects of 1 year of treatment with pioglitazone or rosiglitazone added to glimepiride on lipoprotein (a) and homocysteine concentrations in patients with type 2 diabetes mellitus and metabolic syndrome: A multicenter, randomized, double-blind, controlled clinical trial. Clin. Ther., 2006, 28, 679688.

[323] Sarafidis, P.A.; Lasaridis, A.N.; Nilsson, P.M.; Mouslech, T.F.; Hitoglou-Makedou, A.D.; Stafylas, P.C.; Kazakos, K.A.; Yovos, J.G.; Tourkantonis, A.A. The effect of rosiglitazone on novel atherosclerotic risk factors in patients with type 2 diabetes mellitus and hypertension. An open-label observational study. Metabolism, 2005, 54, 1236-1242.

[324] Almendingen, K.; Jordal, O.; Kierulf, P.; Sandstad, B.; Pedersen, J.I. Effects of partially hydrogenated fish oil, partially hydrogenated soybean oil, and butter on serum lipoproteins and Lp(a) in men. J. Lipid Res., 1995, 36, 1370-1384.

[325] Grekas, D.; Kassimatis, E.; Makedou, A.; Bacharaki, D.; Bamichas, G.; Tourkantonis, A. Combined treatment with low-dose pravastatin and fish oil in post-renal transplantation dislipidemia. Nephron, 2001, 88, 329-333.

[326] Herrmann, W.; Biermann, J.; Kostner, G.M. Comparison of effects of N-3 to N-6 fatty acids on serum level of lipoprotein(a) in patients with coronary artery disease. Am. J. Cardiol., 1995, 76, 459-462.

[327] Lenzi, S.; Caprioli, R.; Rindi, P.; Lazzerini, G.; Bernini, W.; Pardini, E.; Lucchetti, A.; Galli, C.; Carr, L.; de Caterina, R. Omega-3 fatty acid supplementation and lipoprotein(a) concentrations in patients with chronic glomerular diseases. Nephron, 1996, 72, 383-390.

[328] Prisco, D.; Paniccia, R.; Filippini, M.; Francalanci, I.; Bandinelli, B.; Comeglio, P.; Rostagno, C.; Abbate, R.; Neri Serneri, G.G. No 
changes in PAI-1 levels after four-month n-3 PUFA ethyl ester supplementation in healthy subjects. Thromb. Res., 1994, 76, 237244.

[329] Derosa, G.; Cicero, A.F.; Gaddi, A.; Mugellini, A.; Ciccarelli, L.; Fogari, R. The effect of L-carnitine on plasma lipoprotein(a) levels in hypercholesterolemic patients with type 2 diabetes mellitus. Clin. Ther., 2003, 25, 1429-1439.

[330] Rahbar, A.R.; Shakerhosseini, R.; Saadat, N.; Taleban, F.; Pordal, A.; Gollestan, B. Effect of L-carnitine on plasma glycemic and lipidemic profile in patients with type II diabetes mellitus. Eur. J. Clin. Nutr., 2005, 59, 592-596.

[331] Sirtori, C.R.; Calabresi, L.; Ferrara, S.; Pazzucconi, F.; Bondioli, A.; Baldassarre, D.; Birreci, A.; Koverech, A. L-carnitine reduces lipoprotein(a) levels in patients with hyper Lp(a). Nutr. Metab. Cardiovasc. Dis., 2000, 10, 247-251.

[332] Cicero, A.F.; Derosa, G.; Miconi, A.; Laghi, L.; Nascetti, S.; Gaddi, A. Treatment of massive hypertriglyceridemia resistant to
PUFA and fibrates: A possible role for the coenzyme $\mathrm{Q}_{10}$ ? Biofactors, 2005, 23, 7-14.

[333] Cicero, A.F.; Derosa, G.; Miconi, A.; Laghi, L.; Nascetti, S.; Gaddi, A. Possible role of ubiquinone in the treatment of massive hypertriglyceridemia resistant to PUFA and fibrates. Biomed. Pharmacother., 2005, 59, 312-317.

[334] Akaike, M.; Azuma, H.; Kagawa, A.; Matsumoto, K.; Hayashi, I.; Tamura, K.; Nishiuchi, T.; Iuchi, T.; Takamori, N.; Aihara, K.; Yoshida, T.; Kanagawa, Y.; Matsumoto, T. Effect of aspirin treatment on serum concentrations of lipoprotein(a) in patients with atherosclerotic diseases. Clin. Chem., 2002, 48, 1454-1459.

[335] Kagawa, A.; Azuma, H.; Akaike, M.; Kanagawa, Y.; Matsumoto, T. Aspirin reduces apolipoprotein(a) (apo(a)) production in human hepatocytes by suppression of apo(a) gene transcription. J. Biol. Chem., 1999, 274, 34111-34115.

(C) Siekmeier et al.; Licensee Bentham Open.

This is an open access article licensed under the terms of the Creative Commons Attribution Non-Commercial License (http://creativecommons.org/licenses/ by-nc/3.0/) which permits unrestricted, non-commercial use, distribution and reproduction in any medium, provided the work is properly cited. 